\title{
Recent Advances in Nanocomposites Based on Aliphatic Polyesters: Design, Synthesis, and Applications in Regenerative Medicine
}

\author{
Ilaria Armentano ${ }^{1, *}$, Matteo Gigli ${ }^{2, *(\mathbb{D})}$, Francesco Morena ${ }^{3}$, Chiara Argentati ${ }^{3}$, Luigi Torre ${ }^{4}$ \\ and Sabata Martino ${ }^{3}$ \\ 1 Department of Ecological and Biological Sciences, Tuscia University, SNC 01100 Viterbo, Italy \\ 2 Department of Chemical Science and Technologies, University of Rome Tor Vergata, 00133 Rome, Italy \\ 3 Department of Chemistry, Biology and Biotechnology, University of Perugia, 06100 Perugia, Italy; \\ effemorena@gmail.com (F.M.); chiara.argentati89@gmail.com (C.A.); sabata.martino@unipg.it (S.M.) \\ 4 Department of Civil and Environmental Engineering, University of Perugia, 06125 Perugia, Italy; \\ luigi.torre@unipg.it \\ * Correspondence: ilaria.armentano@unitus.it (I.A.); matteo.gigli@uniroma2.it (M.G.)
}

Received: 17 July 2018; Accepted: 19 August 2018; Published: 24 August 2018

\begin{abstract}
In the last decade, biopolymer matrices reinforced with nanofillers have attracted great research efforts thanks to the synergistic characteristics derived from the combination of these two components. In this framework, this review focuses on the fundamental principles and recent progress in the field of aliphatic polyester-based nanocomposites for regenerative medicine applications. Traditional and emerging polymer nanocomposites are described in terms of polymer matrix properties and synthesis methods, used nanofillers, and nanocomposite processing and properties. Special attention has been paid to the most recent nanocomposite systems developed by combining alternative copolymerization strategies with specific nanoparticles. Thermal, electrical, biodegradation, and surface properties have been illustrated and correlated with the nanoparticle kind, content, and shape. Finally, cell-polymer (nanocomposite) interactions have been described by reviewing analysis methodologies such as primary and stem cell viability, adhesion, morphology, and differentiation processes.
\end{abstract}

Keywords: aliphatic polyester; nanocomposites; regenerative medicine

\section{Introduction}

Regenerative medicine aims at the restoration of tissue micro and nanostructures and functions by means of cells and synthetic or natural scaffolds [1-5]. Hence, the development of new materials capable of acting as supporting and temporary architecture for cell proliferation and extracellular matrix deposition, with subsequent tissue ingrowth, plays a critical role in the realization of a new functional tissue. Although various polymeric biomaterials have proved to be useful in the regenerative medicine, special attention has been given to aliphatic polyesters (APs) [6]. APs are biodegradable and/or bio-based, and their properties can be modulated both by chemical routes [7-9] and by physical means by fabricating nanocomposites [10-15]. Despite their potential in various biomedical applications, APs lack surface epitopes, have poor biomechanical properties (e.g., low modulus or brittleness), and longer degradation times, e.g., poly( $\varepsilon$-caprolactone), thereby necessitate the incorporation of additional molecules or nanofillers to modulate these characteristics.

Efficient strategies have been studied to obtain polyesters applicable in biomedicine and many members of the family have been so far commercialized. Many efforts have been recently made to improve the properties and make APs more competitive as compared to petroleum-based 
polymers. In this respect, polymer blends, copolymerization strategies, and nanocomposites have been extensively studied [16-20].

On the other hand, nanotechnology, which deals with materials of about 0.1 to $100 \mathrm{~nm}$ size, offers new methods to modify material properties. In particular, the recent combination of promising nanotechnology with biology, medicine, and material science has resulted in many innovative nanoengineering efforts applicable on the repair and regeneration of specific tissues, organs, and functions [11]. Hence nanoengineering interdisciplinary approaches applied to biomedicine may contribute to address the main issue of personal and global health care. Furthermore, the combination of chemical methods for modifying existing polymers with nanocomposite approach could open up new perspectives in advanced functional material development.

This review highlights the recent advances in nanocomposites based on aliphatic polyesters in terms of design, synthesis, and applications in regenerative medicine. Structure-properties relationships of the resulted materials and their potential applications will be mainly investigated.

\section{Materials}

\subsection{APs for Biomedical Applications}

APs were firstly prepared by Carothers in the early 1930s. His research started at DuPont and established a firm starting point for systematic studies on linear polyester development. Further investigations by Flory (a former Carothers' coworker) at Cornell University [21-24] were focused on polyesterification kinetics and on molecular weight distribution. However, some characteristics of APs, such as sensitivity to hydrolysis, low melting temperature, and solubility in common organic solvents were seen as detrimental for practical uses, leading to a significant stop in their further development. More recently, the need for ecofriendly materials generated new interest in APs, which resulted particularly attracting because of their intrinsic biodegradability. In the following, APs employed in biomedicine are described more in detail. Their chemical structure is depicted in Figure 1.<smiles>CC(C)CC(=O)O</smiles>

Polyglycolic acid (PGA)<smiles>CC(COCCCCCC(=O)O)C(=O)O</smiles><smiles>CCCC(=O)OCCCCOC(C)C</smiles>

Poly(butylene succinate) (PBS)<smiles>CC(C)OC(C)C(=O)O</smiles>

Polylactic acid (PLA)<smiles>[R]C(CC(=O)O)OC(C)C</smiles>

Polyhydroxyalkanoates (PHA)<smiles>O=C(O)C1CCC(C(=O)OCCCO[Tl])CC1</smiles>

Poly(butylene 1,4-cyclohexanedicarboxylate) (PBCE)

Figure 1. Chemical structure of aliphatic polyesters (APs) used for biomedical applications. 


\subsubsection{Poly(glycolic acid)}

Poly(glycolic acid) (PGA) is the first hydrolyzable polymer employed in biomedicine, as it has been used since 1970 as degradable suture DEXON ${ }^{\circledR}$ [25]. More recent work aimed at the development of short-term scaffolds for tissue engineering purposes and of PGA-based blends. Although significant research has been carried out on this material, there exist important concerns related to PGA. Indeed, a fast hydrolysis rate leads to mechanical failure and to a local production of considerable amounts of glycolic acid. Although this latter can be bioresorbed via the citric acid cycle [26], high levels of glycolic acid cause a strong, undesired inflammatory response.

\subsubsection{Poly(lactic acid)}

Lactic acidis a chiral molecule. Therefore, three different stereoisomers of lactide (formed from two lactid acid molecules) exist: L,L-lactide, D,D-lactide, and meso-lactide. Consequently, poly-L-lactide (PLLA), poly-D-lactide (PDLA), and poly-DL-lactide (PDLLA) can be obtained. Regarding their application in biomedicine, only PLLA and PDLLA have displayed promising potential and have been widely investigated. Due to the presence of an additional methyl group in the monomeric unit, PLA results more hydrophobic, thus its hydrolysis rate is slower than that of PGA. It has been reported that it takes more than 1 year for PLLA to be completely resorbed in vivo [27]. PLLA has been employed for a wide range of tissue engineering purposes, such as bone, cartilage, tendon, neural, and vascular regeneration [28]. To speed up degradation rate, PLLA has been blended or copolymerized with other hydrolyzable (bio)polymers. Blends, composites, and nanocomposites have been prepared by combining PLLA with PDLLA, poly( $\varepsilon$-caprolactone) (PCL), poly(ethylene glycol) (PEG), collagen, chitosan, and so on [16]. On the other hand, PDLLA is fully amorphous due to the randomic distribution of the two stereoisomers along the macromolecular chain. As PLLA, also PDLLA has been utilized for tissue engineering applications, both alone or in combination with other degradable polymers to obtain composites with tailored characteristics [17].

\subsubsection{Poly(lactide-co-glycolide)}

Random copolymerization of lactide (both L,L- and D,L-lactide forms) and glycolide leads to the synthesis of poly(lactic-co-glycolic) acid (PLGA), which is probably the most studied hydrolyzable polyester in biomedicine. It has been employed in sutures (since 1974 under the trade name Vicryl ${ }^{\circledR}$ ), drug delivery and scaffolds for tissue regeneration, as it displays very high biocompatibility $[29,30]$. PLGA-based scaffolds have been produced through a plethora of techniques such as gas foaming, microsphere sintering, porogen leaching, electrospinning, and polymer printing, with the aim of obtaining a unique combination of microstructure and physical/mechanical properties capable of favoring tissue growth [17].

\subsubsection{Poly( $\varepsilon$-caprolactone)}

PCL is synthesized by ring-opening polymerization (ROP) of the cyclic monomer $\varepsilon$-caprolactone [31]. Since PCL shows very low hydrolysis rate due to its high degree of crystallinity, it has been used since the '70s as a long-term resorbable sutures and implants. PCL is commonly blended with other polyesters and polyethers and PCL-based copolymers are obtained by copolymerizing $\varepsilon$-caprolactone with other cyclic esters with the main purpose of accelerating its hydrolysis [30]. This polyester has been greatly employed in tissue engineering applications: PCL and PCL composites have been explored for bone, ligament, cartilage, skin, nerve, and vascular tissue engineering purposes $[11,18,32,33]$. 


\subsubsection{Polyhydroxyalkanoates}

Polyhydroxyalkanoates (PHA) are polyesters usually obtained by microbial fermentation, although they can also be synthesized via synthetic routes. Microorganisms produce PHA as energy source and carbon storage when excess of carbon source and deficiency of other nutrients is present [34]. More than 100 different PHA are known; among them, the most well-known member is poly(3-hydroxybutyrate) ( $\mathrm{PHB})$, a semicrystalline isotactic polymer. Its degradation proceeds via surface erosion because of the hydrophobicity of its macromolecular chain and the high degree of crystallinity [35]. Hydrolysis of PHB leads to the development of D-(-)-3-hydroxybutyric acid, a blood constituent [36]. PHB is a great candidate for long-term tissue engineering purposes because of the excellent biocompatibility and good combination of physical/mechanical and degradation characteristics [17].

\subsubsection{Poly(butylene succinate)}

Poly(butylene succinate) (PBS) is produced starting from succinic acid (SA) and 1,4-butanediol (BD). Albeit these raw materials are usually derived from fossil resources, pathways for the synthesis of SA and BD from renewable resources have been recently discovered. PBS is a thermoplastic polyester displaying a melting point $\left(\mathrm{T}_{\mathrm{m}}\right)$ of $115{ }^{\circ} \mathrm{C}$ ca., one of the highest among poly(alkylene dicarboxylate)s, [37] and glass transition temperature $\left(\mathrm{T}_{\mathrm{g}}\right)$ of about $-35{ }^{\circ} \mathrm{C}$. With respect to the above mentioned APs, PBS use for biomedical uses has been only recently explored and interesting biocompatibility outcomes have been reported [19]. PBS homopolymer, PBS-based copolymers, and nanocomposites have mainly been tested for tissue engineering and, to a minor extent, for drug delivery purposes.

\subsubsection{Poly(butylene 1,4-cyclohexanedicarboxylate)}

Poly(butylene 1,4-cyclohexanedicarboxylate) (PBCE) is prepared by polycondensation of BD and cyclohexanedicarboxylic acid. The presence of an aliphatic ring in the monomeric unit high affects the material physical and functional properties. The trans stereoisomer is more symmetrical than the cis one and enhances chain packing and crystallization ability and perfection. When the trans isomer is employed, $\mathrm{PBCE}$ is a semicrystalline polymer displaying a $\mathrm{T}_{\mathrm{m}}$ of $166^{\circ} \mathrm{C}$ ca., a $\mathrm{T}_{\mathrm{g}}$ of $12{ }^{\circ} \mathrm{C}$, and an elastic modulus of about $450 \mathrm{MPa}$ [20]. Due to the low stretchability and high hydrophobicity, to be employed for tissue engineering PBCE has been copolymerized with more flexible co-units, e.g., containing polar ether and thioether linkages [38-40].

\subsection{Polymer Synthesis}

Two main methods for the synthesis of APs exist. They can be prepared by polycondensation of bifunctional raw materials, like self-condensation of hydroxy acids, condensation of diacids with diols, diacid chlorides with diols, or by transesterification reactions of diesters and diols [41]. Alternatively, APs can be obtained by ROP of lactones and lactides [42]. Pioneering research on polycondensation unveiled the formation, together with expected high molecular weight linear polyesters, of low molecular weight cyclic byproducts. Some of them, e.g., $\varepsilon$-caprolactone, were purified and used as raw materials in the ROP, eventually leading to the synthesis of APs. However, it was necessary to wait a few decades for the methods of controlled polymerization of cyclic esters to be fully exploited.

Nowadays, commercially available APs are synthesized employing both strategies. Polycondensation can be used for many different diols and diacids, but it usually requires high temperature, long reaction time, and removal of reaction byproducts for the achievement of high molar mass materials [43]. Furthermore, the final polymers do not display controlled chain lengths, and molecular weight distribution is about two. On the other hand, only a limited number of raw materials can be employed for ROP, but it can be performed under milder conditions, and high molar mass polymers can be obtained in shorter reaction times. A wide range of initiators and 
catalysts have been studied for ROP [42]. In the more favorable case, ROP of lactones and lactides is a living/controlled reaction, thus by controlling the monomer-to-initiator molar ratio it is possible to predetermine the molecular weight of the final polymer. The most used initiator for ROP of APs is tin(II) bis-(2-ethylhexanoate), also called tin octoate $\left(\mathrm{Sn}(\mathrm{Oct})_{2}\right)$. Since it has been authorized as food additive by the US Food and Drug Administration (FDA), its removal from the final product is not necessary [42]. More recently, also the enzymatic catalysis has been explored for APs synthesis [43]. Generally speaking, enzymatic reactions can be performed under very mild conditions. More importantly, enzymes can easily achieve high regiospecificity and stereospecificity [44]. Lipase catalyzed polymerization has been studied as ecofriendly alternative for the preparation of APs. Indeed, lipases are capable of catalyzing both the ROP of lactones (small to large rings) and cyclic diesters (lactides) and the polycondensation of hydroxy acids and diacids with diols.

\subsection{Copolymerization Strategies}

Copolymerization attracts much attention because it permits to easily tune the material characteristics. In fact, the functional characteristics of the copolymers can be tailored by varying the kind, relative content, and distribution of the comonomeric units along the macromolecular backbone. Most copolymers are developed to display synergistic properties as compared the parent homopolymers, such as improved thermal and mechanical stability, better processability, and higher chemical resistance.

\subsubsection{Random Copolymers}

APs random copolymers are easily obtained by melt polycondensation of a diacid (or diester) with two diols of comparable reactivity or of two diacids (or diesters) of comparable reactivity with a diol. Usually, the high temperatures involved in the process and the use of appropriate catalysts, such as titanium tetrabutoxide favor the transeterification reactions leading to the formation of random copolyesters [39,40]. Simultaneous ROP of more than one (di)lactone is another well-known strategy that leads to the formation of random copolyesters [45,46].

\subsubsection{Reactive Blending}

Reactive blending is a particular technique used to compatibilize immiscible polymers thanks to chemical reactions triggered during the melt mixing process. Contrary to physical blending, which needs a further step for the development of an appropriate compatibilizing agent, reactive blending is very straightforward and cost-effective [47]. It can be conducted in solution, in the molten or even in the solid state. Among those, melt processing displays many benefits. In fact, the use of solvents can be avoided, thus decreasing the costs required for their removal, recovery, and losses, and reducing the environmental impact. Secondly, the use of an extruder as a continuous reaction vessel offers additional advantages such as better temperature control, pumping efficiency over a broad viscosity range and economic savings achieved by combining many distinct steps in a single processing device [48].

It must be pointed out that reactive blending occurs in the melt at high temperature, therefore the thermal stability of the reacting groups and of the formed chemical bonds may must be taken in due consideration [49]. As a consequence, only a few chemical reactions are suitable for reactive blending, such as interchange reactions between polycondensates [49].

In this framework, the use of reactive blending for copolyester synthesis appears to be a particularly interesting solution which has been broadly explored [50-52]. The interchange reactions mainly involved are intermolecular alcoholysis, acidolysis, and esterolysis. During the process, by increasing the reaction time, the molecular architecture of the formed copolymers evolves from long blocks to random co-unit distribution (Figure 2). Furthermore, it has been reported that the longer the reaction time, the higher the molar mass of the obtained copolyesters, since transesterification reactions prevail over chain scissions [51,52]. 

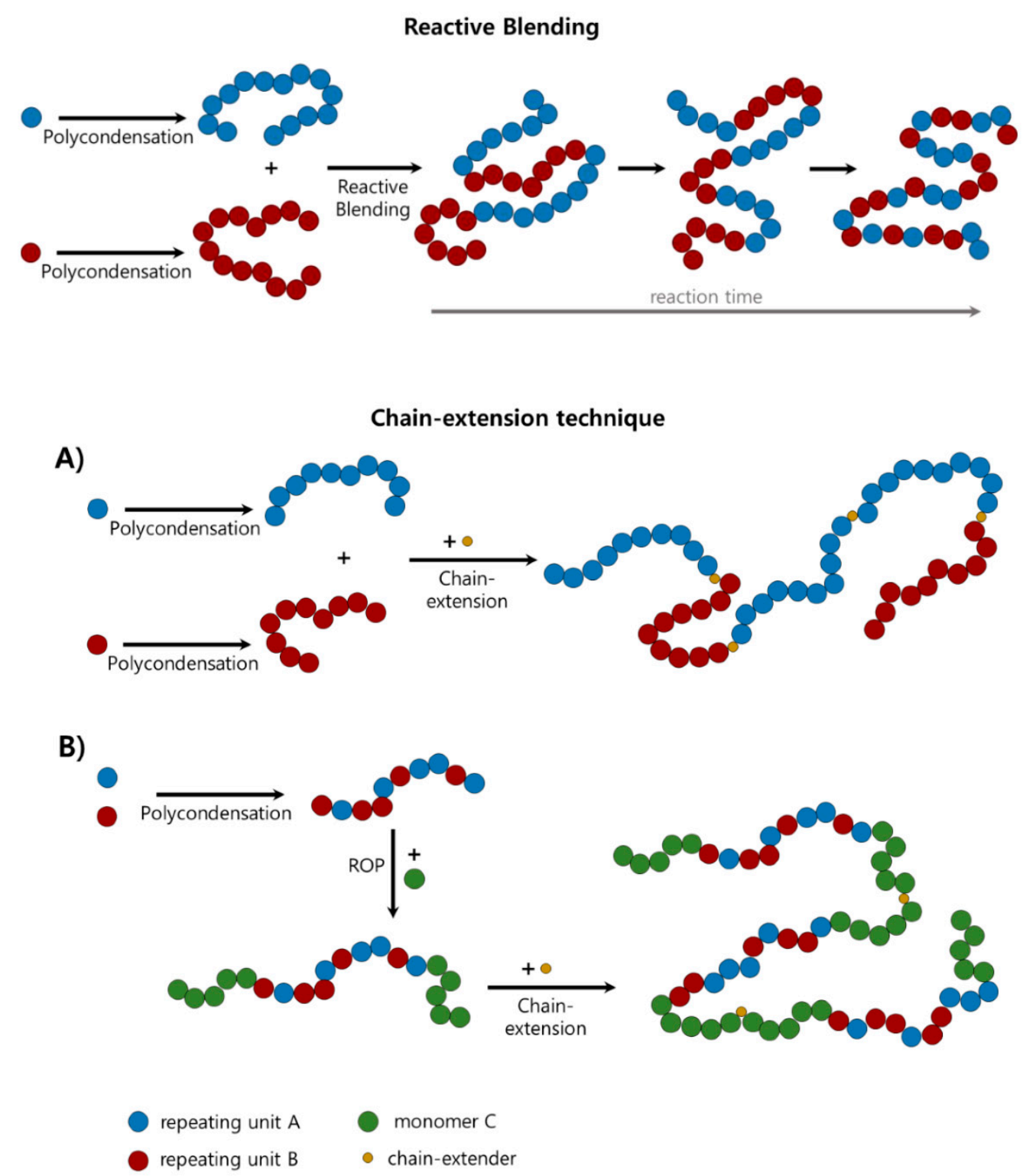

Figure 2. Copolymerization strategies. Evolution of the molecular architecture as a function of the mixing time during reactive blending (above); chain extension reactions (below): (A) coupling of two $\mathrm{OH}$-terminated prepolymers for the preparation of random multiblock copolymers and (B) polycondensation of a OH-terminated (co)polymer followed by ring-opening polymerization of a lactone monomer and subsequent chain-extension for the synthesis of A-B-A type multiblock copolymers.

\subsubsection{Chain-Extension Technique}

Although copolymerization still remains the most exploited way of modulate polymer properties, it suffer of some inevitable drawbacks. In particular, when a significant amount of comonomeric units is inserted in the macromolecular chain, a drastic decrease of the melting point and a worsening of mechanical strength is usually observed. Furthermore, as above reported, the achievement of high and controlled molecular weight polymers through polycondensation may be troublesome.

In this view, the use of chain extenders may help overcome these limitations. For the preparation of APs, the coupling of diisocyanates with hydroxyl-terminated polyesters has been investigated [53-56]. Through this technique, it is possible to obtain high molar mass poly(ester urethane)s (PEU) showing optimized functional properties for the intended application. Indeed, by varying the number, 
chemical structure, and relative content of the $\mathrm{OH}$-terminated prepolymers, a wide range of new materials become available. In addition, two main pathways can be explored leading to different molecular architectures. On the one hand, by combining two or more $\mathrm{OH}$-terminated (co)polyesters obtained by polycondensation, random multiblock structures will be achieved [53-55] (Figure 2A). On the other hand, by exploiting the hydroxyl terminal groups of a (co)polyester for the ring opening reaction of a lactone, triblock copolymers can be easily prepared (Figure 2B). These latter can be then chain-extended with diisocyanates to form alternating multiblock copolymers [57].

\subsection{Nanofillers}

Different nanofillers have been used in combination with APs to develop new materials with enhanced properties. In this review, we mainly focus on conductive fillers such as carbon nanotubes and bio-based organic fillers as cellulose nanocrystals.

Carbon nanostructures are some of the most important innovative products of nanotechnology, since the discovery of fullerenes, carbon nanotubes (CNTs), carbon nanofibers (CNFs), graphene, and other carbon related forms [58-61]. Carbon nanotubes (CNTs) can be viewed as one or more graphene sheet rolled in a cylindrical way. Single walled carbon nanotubes (SWCNTs) have the diameter typically around $1 \mathrm{~nm}$ and length until some micrometer and are tubes made of a single sheet of graphene, while multi walled carbon nanotubes (MWCNTs) are made from more graphene sheets, so the diameter increases with respect to SWCNTs, until 10-20 nm [62]. The most important properties of CNTs cannot be attributed to the nanometer dimension, rather to the higher aspect ratio, that is the ratio between the length and the diameter of CNTs. Furthermore, CNTs display extraordinary mechanical, thermal, and electrical properties, they have ordered structure, ultralight weight, high mechanical strength, high electrical conductivity, high thermal conductivity, metallic or semi-metallic behavior, and high surface area, that can be correlated with the morphology and the high aspect ratio. The synthesis methods for carbon nanostructures include laser vaporization, arc discharge, catalytic chemical vapor deposition (CVD), and catalytic plasma-enhanced chemical vapor deposition (PECVD). Pristine CNTs are naturally hydrophobic, hence they lack of solubility in most solvents used with APs. To overcome this problem, CNT functionalization is achieved by adsorption, electrostatic interaction, or covalent bonding of different molecules and chemistries [62]. In combination with APs, CNTs were mainly used to modulate the bulk properties of the polymeric matrix, such as thermal, mechanical, and electrical properties [10-13].

Among bio-based organic fillers, cellulose nanostructures are a class of fascinating nanomaterials that recently have received a great interest both in industry and academia research, owing to their unique structural physicochemical properties such as biodegradability, renewability, low density, adaptable surface chemistry, optical transparency, and improved mechanical properties [63]. Cellulose is one of the most ubiquitous and abundant polymers on the planet, given its widespread industrial use in the present age. Cellulose is widely distributed in higher plants, in several marine animals (i.e., tunicates), and to a lesser degree in algae, fungi, bacteria, invertebrates, and even amoeba (protozoa). In general, cellulose is a fibrous, tough, water-insoluble substance that plays an essential role in maintaining the structure of plant cell walls. Cellulose fibers with nanometer dimensions can be isolated from the wood cell wall by using different methods, i.e., by chemical and mechanical treatments. The high elastic modulus of cellulose, together with improved thermal stability, decreased thermal expansion, and increased thermal conductivity, makes cellulose in general, and nanocellulose in particular, highly interesting for use as reinforcement in polymer nanocomposite materials. Cellulose nanostructures can be used to modulate important APs properties such as mechanical behavior, with the aim of developing fully bio-based nanocomposites [14,15]. 


\section{Nanocomposite Processing}

Processing of nanocomposites based on APs involves the incorporation of nanoparticles within the polymer matrix, to produce a new material, displaying a nanometric dispersion of the selected particles. Generally, a nano-homogeneous level of nanoparticles has to be achieved in order to obtain a modulation of the biopolymer properties.

The primary function of the processing method is thus to guarantee an adequate nanolevel dispersion of the particles in the biopolymer matrix, with a structural integrity of the nanoparticles. Furthermore, important points are also to avoid the adverse effects on the polymer. A variety of processing techniques can be exploited to develop dense polymer nanocomposite films [10-13,38,64] or three-dimensional porous structures $[65,66]$. The selection of the processing method depends on the type of biopolymer, on the nanoparticle, and the final application.

The incorporation of micro- and nanostructures into polymer can be done in different ways that can be generally divided in:

a Solvent casting methods

b Melt mixing methods

Solution methods involve dissolution of the polymer matrix in an appropriate solvent with nanoparticles followed by either solvent evaporation or precipitation. The polymer solvent casting method represents a low-cost and rapid strategy, widely used for the processing of flexible biopolymer blend and bio-nanocomposite films for various applications [67]. The polymer is typically dissolved in a specific solvent while the nanoparticles are dispersed in the same or in another solvent; afterwards, the two parts are mixed together. The effect of solvent in the film processing and in the material properties is a key point that needs to be elucidated. Indeed, the selected solvent influences the film properties, in terms of thermal, mechanical, and surface properties, of homogeneity of the surface micro and nano-structure, reorientation or mobility of the surface crystal segment, swelling, and deformation $[10-13,38,64,68]$. Polymer solubility is one of the main points to analyze and study in terms of temperature dependence and the solubility limit. The interfacial adhesion between the polymer and the nanoparticles and the solvent casting mixing conditions during fabrication of biopolymer-based films strongly affect the network structure of the film, physical and chemical properties, and final film performance. The solution with biopolymer based blends or bio-nanocomposite is finally deposited in an open mold until complete evaporation. Furthermore, the evaporation conditions, in terms of humidity, temperature, and pressure strongly affect evaporation rate of the solvent, that it is strictly related with the obtained surface morphology.

Furthermore, in the casting process, the film quality is strongly related to the rheological behavior of the film-forming solution. Solution mixing has been widely used in order to produce nanocomposites based on carbon nanostructures as CNTs or graphene. However, these materials are very cohesive due to Van der Waals bonds between the carbon atoms. Achieving the desired dispersion is not easy in the liquids owing to their strong tendency for agglomeration; hence, in order to reduce the agglomeration and to obtain nanofiller dispersion in a liquid, an ultrasonication process is generally applied. First, the polymer matrix and the fillers are dissolved in a solvent and (only at this stage) the filler solution is exposed to ultrasonication. After, the two solutions are mechanically mixed together until a homogenous mixture is achieved. Finally, the solvent is evaporated from the suspension $[10-13,38,64,68]$.

The processing of polymer nanocomposites (PNs), based on thermoplastic polymer matrices by conventional polymer melt compounding methods represents a promising approach to obtain a good nanoparticle dispersion and to greatly expand the commercial opportunities for this technology. Melt compounding would allow nanocomposites to be directly formulated using ordinary compounding devices such as extruders or other melt mixers according to the specific needs. [14,15]. In the melt processing technique, nanoparticles are mechanically mixed with the polymer in the molten state. Processing temperatures and residence time need to be selected according to the thermal 
main transitions of both the polymer and the nanoparticles. In particular, the polymer melting and the thermal degradation temperatures in oxidative atmosphere have to be known in order to select a suitable process temperature, i.e., higher than melting temperature $\left(\mathrm{T}_{\mathrm{m}}\right)$ and significantly lower than the degradation. Furthermore, mainly for bio-based nanoparticles, their thermal degradation temperature plays a key role in determining the mixing conditions.

In the case of bio-nanocomposites development, melt processing approach displays a possible drawback. The effect of the increased temperature combined with the mechanical shearing force applied during the mixing can cause polymer degradation. This effect is mainly visible if a biopolymer is processed. It is indeed well-known that for example PLA experiences processing instability, hence thermal, oxidative, and hydrolytic degradation may occur during processing, which lead to the cleavage of polymer chains and, as a result, a decrease of molecular weight $[69,70]$.

For the development of 3D-ordered structures different processes have been optimized. In particular, electrospinning, additive manufacturing, 3D printing, and gas foaming are nowadays the mainly used for biomedical applications [71-73].

\section{Properties}

\subsection{Thermal Properties}

Thermal analysis covers a number of methods in which changes in physical properties of a material are measured as a function of temperature. It can be therefore applied to PN in order to gain further insight into their structure and thermal behavior. In this section, differential scanning calorimetry (DSC) and thermogravimetric analysis (TGA) are discussed.

\subsubsection{DSC}

Differential scanning calorimetry has been widely applied in the investigation of the polymer and polymer nanocomposite thermal transitions, namely glass transition, melting, and crystallization temperatures and related enthalpies. Usually DSC thermal analysis in AP-based systems is conducted by performing three different scans. The first scan is used to evaluate any processing effect on the polymeric material, or to delete the thermal history. The second scan, i.e., a cooling scan, can be conducted at a slow or at a fast rate (quenching), depending on whether the crystallization ability needs to be suppressed (e.g., to highlight the glass transition phenomenon) or not. One last heating scan is run to evaluate the characteristic thermal transitions. The thermal transition temperatures of the most well-known APs are reported in Table 1 together with those of PBS and PBCE. With the exception of PGA and PLA-based homopolyesters, they all display a $\mathrm{T}_{\mathrm{g}}$ below room temperature. It can be noted that the $T_{g}$ of PBCE is higher than that of PBS because of the chain rigidity imparted by the aliphatic ring [74].

Table 1. Thermal properties of the main aliphatic polyesters.

\begin{tabular}{cccc}
\hline Polymer & $\mathrm{T}_{\mathbf{g}}\left({ }^{\circ} \mathbf{C}\right)$ & $\mathrm{T}_{\mathbf{m}}\left({ }^{\circ} \mathrm{C}\right)$ & Ref. \\
\hline PLLA & $55-65$ & $170-200$ & {$[27]$} \\
PDLLA & $50-60$ & Amorphous & {$[27]$} \\
PGA & $35-45$ & $220-233$ & {$[27]$} \\
PCL & $(-65)-(-60)$ & $56-65$ & {$[33]$} \\
PHB & 9 & $175-180$ & {$[36]$} \\
PBS & $(-37)-(-30)$ & $111-115$ & {$[19]$} \\
PBCE & 12 & 167 & {$[20]$} \\
\hline
\end{tabular}


In random copolymers, glass transition is often a monotonic function of composition and the most common equation employed to foresee it as a function of comonomer amount is the Fox one [75]

$$
1 / T_{g}=\omega_{A} / T_{g, A}+\omega_{B} / T_{g, B}
$$

where $T_{g, A}$ and $T_{g, B}$ are the glass transition temperatures of the homopolymers and $\omega_{A}$ and $\omega_{B}$ the corresponding weight fractions. In this regard, APs random copolymers make no exception. Studies have demonstrated the linear variation of $\mathrm{T}_{\mathrm{g}}$ with the molar composition in PBS-based copolyesters and the applicability of a Fox-type equation for the determination of the $\mathrm{T}_{\mathrm{g}}$ of fully amorphous PBS [76].

It has been observed that the insertion of ether and thioether linkages along the macromolecular backbone of APs has a significant influence on the glass transition temperature. Two opposite factors play a role in this respect, and one of the two can prevail depending on the copolymeric system. On one hand, there is a flexibility enhancement that causes a decrement of $T_{g}[42,51,52]$. On the other hand, the presence of polar atoms can raise the $T_{g}$ because of stronger interchain interactions [76]. Notwithstanding a similar chemical structure, blends of two APs can be immiscible, thus presenting two distinct $\mathrm{T}_{\mathrm{gs}}$ [19]. The reactive blending strategy permitted to overcome this limitation, already for short reaction times, i.e., long copolymeric sequences, as a single $\mathrm{T}_{\mathrm{g}}$ was observed $[19,50,51]$. The chain extension of hydroxyl-terminated prepolymers, which led to the formation of multiblock copolymers, also evidenced a complete miscibility of the final materials in the amorphous phase [53-55]. As to the melting process, DSC traces of APs may show multiple melting peaks that have been imputed to melt-recrystallization phenomena that take place during the DSC scan [13]. Furthermore, a decrease of $\mathrm{T}_{\mathrm{m}}$ is usually recorded by increasing the content of comonomeric units in random copolymers. In particular, if both parent homopolymers are able to crystallize, by plotting the degree of crystallinity and the $\mathrm{T}_{\mathrm{m}}$ as a function of the copolymer molar composition, a minimum in the two properties is usually observed when significant amounts of both co-units are present, regardless there is co-crystallization or complete rejection of the co-units from the crystalline domains $[76,77]$. This is because the co-monomeric units hamper the efficient packing of the homopolymer sequences as the perfection of the crystalline domains is highly affected by the chain regularity [78]. The reactive blending also causes a progressive reduction of the $T_{m}$ of the prepared copolyester with the increase of the mixing time, i.e., the decrease of the block length. On the other hand, through the chain-extension strategy, it is possible to limit this issue. Indeed, the coupling of $\mathrm{OH}$-terminated prepolymers with an acceptable molecular weight (e.g., $\mathrm{Mn}>5000 \mathrm{~g} / \mathrm{mol}$ ) allows for the preservation of the crystallization ability of the homopolymeric sequences even in triphasic systems $[53,54]$. Thermal transitions of APs are affected by the presence of nanofillers. Several studies have focused on PLA-based nanocomposites and have been recently reviewed [79,80]. In general, independently of the employed nanofiller, e.g., CNTs, graphene, or graphene oxide (GO), an increase of the melt crystallization kinetics is observed, as the nanoparticles act as heterogeneous nucleating agents for the polyester matrix crystallization. Consequently, the degree of crystallinity and $\mathrm{T}_{\mathrm{m}}$ are enhanced, as due to the formation of a higher amount of more perfect crystals [12]. Usually, a threshold exists above which the particle loading is too high and a worsening of the crystallinity is detected, as due to agglomeration and poor nanometric dispersion [79]. A similar behavior has been reported for PBCE-based nanocomposites containing SWCNTs [13]. Indeed, an increment of the melting enthalpy and a disappearance of the melting and recrystallization peaks was detected, indicating an increase of the crystalline content and perfection. Increase of crystallization rate, due to particle nucleating effect, has also been observed in PCL-based nanocomposites containing nano- $\mathrm{CaCO}_{3}$ and in PBS-based nanocomposites loaded with different clays [81]. On the contrary, the influence of nanoparticles on the polymer glass transition is less evident. In some cases, no variation has been recorded [13,80,82], in others a slight $T_{g}$ increase has been detected and ascribed to a good interaction between polymer matrix (PLA) and nanofillers, which restricted the macromolecular mobility by hydrogen bonding and electrostatic interactions [79]. 


\subsubsection{TGA}

TGA is a commonly used technique to characterize the thermal stability and decomposition pattern of materials under various conditions and to detect the occurring physicochemical processes by measuring the weight changes as a function of temperature. In APs, TGA can be employed to investigate the effect of copolymerization and nanoparticle presence and content on the polymer matrix. Furthermore, important information on sample processability can be gained. In particular, two main data should be taken into consideration: the thermal decomposition temperatures and the residual mass (usually measured under nitrogen atmosphere at $600^{\circ} \mathrm{C}$ ). At this temperature, the macromolecular backbone is completely degraded, hence the residual mass can be ascribed only to the presence of nanofillers. Furthermore, by performing more replicates, the standard deviation error in the residual mass can give information on filler dispersion, i.e., nanocomposite homogeneity. Thermal stability of block and random copolymers is usually comprised between that of the parent homopolymers, and it slightly varies with the molar composition $[51,76]$. On the other hand, thermogravimetric analysis performed on numerous APs-based nanocomposites demonstrated the beneficial influence of nanoparticles, which are responsible of an improvement of the thermal stability, that is, higher thermal degradation onset. This effect is particularly important for APs that display not excellent thermal resistance, such as PLA [83]. On the contrary, other APs, such as PBS and PBCE, show thermal stability well above $300^{\circ} \mathrm{C}$; in the latter case even superior to the corresponding aromatic polyester, i.e., poly(butylene therephthalate) (PBT) [73]. Different works have analyzed the thermal stability of PLA containing carbon-based nanomaterials $(\mathrm{CBN})$, and an increase in the degradation temperatures has been ascribed. This effect has been correlated to different factors: (a) good dispersion and compatibility between polymer and fillers, leading to PLA restricted chain motions which can retard degradation; (b) formation of a crystallization layer on nanocomposite surface capable of absorbing some of the heat supplied during TGA experiments; and (c) CBN can create a "tortuous path" which delays oxygen permeation and out-diffusion of volatile decomposition products [79]. The introduction of nanosilica in PLA matrix also permitted to increase the polymer thermal stability, making the nanocomposite processable [81]. The addition of montmorillonite to poly(3-hydroxybutyrate-co-3-hydroxyvalerate) (PHBV) resulted in an intercalated structural morphology with improved thermal stability, as it supplied an effective oxygen permeation barrier [84]. In another study, scaffolds loaded with cellulose nanocrystals (CNC) and reduced graphene oxide ( $\mathrm{rGO}$ ) showed an increased thermal stability as compared to neat PLA. The addition of both fillers generated a synergistic action [85]. On the other hand, recent work demonstrated that cellulose nanocrystals did not have any influence on the thermal decomposition of PBS and PBS-based copolymers [14], as well as that SWCNTs did not affect the degradation behavior of PBCE and PBCE-based copolymers at low weight content [13].

\subsection{Biodegradation Properties}

(Bio)degradation rate and mechanism are crucial factors to be considered in the design of biomaterials for regenerative medicine. Indeed, the construct should not only support cell growth and proliferation, but also degrade in a controlled way and at a proper rate, i.e., comparable with the formation of the new tissue. Most importantly, it should bear loading conditions until the fresh tissue will be able to take them up and the degradation products must be not toxic.

Polymers capable of being degraded by cell-mediated phenomena should be called biodegradable [86]. On the other hand, polymer degradation resulting solely from the action of the water present in tissues and organs should be referred to as hydrolytic degradation [86]. APs undergo both hydrolysis and enzymatic degradation (Figure 3). 


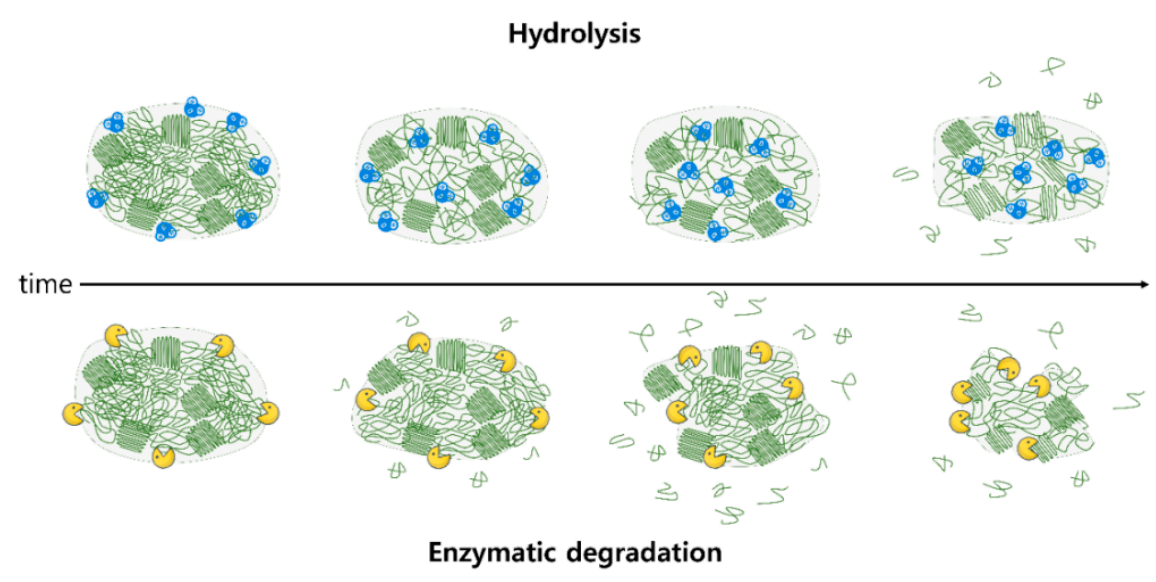

Figure 3. Cartoon representing hydrolysis and enzymatic degradation process as a function of the incubation time for aliphatic polyesters.

\subsubsection{Hydrolysis}

Esters, orthoesters, ethers, anhydrides, amides, carbamides (ureas), and ester amides (urethanes) are among the chemical bonds that can be cleaved by the action of water [87]. The bond kind determines also the hydrolysis rate. Anhydrides and orthoesters are the most susceptible to water degradation, followed by ester and amide linkages. It must be noted that hydrolysis rate can significantly vary depending on the conditions (e.g., temperature, $\mathrm{pH}$, etc.), the presence of catalysts, and on the chemical neighborhood, since different functional groups may have an electronic and/or steric influence [88].

Two main degradation routes can be highlighted: bulk and surface erosion, depending of the water diffusion rate. If water diffusion is faster than bond cleavage, the material will undergo bulk erosion, vice versa when the bond scission is faster than water diffusion, the polymer will be degraded by surface erosion.

APs hydrolysis occurs in bulk and involves various steps, i.e., water absorption, ester bond scission, neutralization of carboxyl end groups at the surface, autocatalysis, and diffusion and solubilization of soluble oligomers [89] (Figure 3). In other words, water penetrates the polymer matrix (with or without swelling) and activates the polymer degradation, leading to the formation of oligomers and monomers [88] through the following reaction:

$$
\mathrm{RCOOR}^{1}+\mathrm{H}_{2} \mathrm{O} \leftrightarrow \mathrm{RCOOH}+\mathrm{R}^{1} \mathrm{OH}
$$

Hydrolysis is catalyzed by acid or basic compounds. Thus, RCOOH byproducts are capable of accelerating the hydrolysis by an autocatalytic process. Macroscopically, two steps can be highlighted. The first one results in random cleavage of the macromolecular chains together with molecular weight reduction, which leads to a worsening of the mechanical properties, while weight losses are negligible $[53,90]$. In the second step, the molecular fragments are solubilized with concomitant mass loss [91].

\subsubsection{Enzymatic Degradation}

The products of enzymatic degradation and hydrolysis are the same, but the two pathways differ in the catalyst involved. The cleavage of ester bonds of APs is mediated by lipases, cutinases, serine proteases, PHB depolymerase, PCL depolymerase, elastase esterase, proteinase $\mathrm{K}$, and trypsin [92]. Enzymatic degradation is therefore a heterogeneous process, which occurs via two steps of adsorption and hydrolysis. First, the hydrophobic sites of enzymes adhere to solid substrates by hydrophobic interactions, then through their catalytic sites favor the polymer hydrolysis. Contrarily to hydrolysis, enzymatic degradation is a surface eroding process, which only proceeds on the outer layer of the substrate, since the enzyme is not capable of penetrating the polymer matrix 
(Figure 3). Thus, through enzymatic degradation the polymer weight decreases, while molecular weight and polydispersity do not significantly vary [91]. The low molecular weight degradation products are solubilized in the surrounding aqueous medium. To monitor the evolution of the enzymatic degradation, especially during the initial stages, simple yet effective techniques can be used. In particular, the surface crystallinity increase can be measured by infrared spectroscopy in attenuated reflection mode (ATR-FTIR), and the increase of surface roughness and opacity can be evaluated by a semiquantitative film opacity assay [93].

Two degradation mechanisms exist, since bond cleavage can occur either at random points along the macromolecular backbone (endo-type degradation) or at the ends of the polymer chain (exo-type degradation). Lipase or PHA depolymerase action is based on endo-type bond cleavage, therefore it does not depend on molar mass and polydispersity index.

Recently, mild enzymatic degradation of PLLA has been exploited with the aim of introducing hydroxyl and carboxylic groups on the polymer surface by employing Humicola insolens cutinase [94-96]. The studies demonstrated the suitability of cutinase-mediated processes to functionalize PLA surface in a controlled fashion, since no effect on the bulk characteristics of the polymer were recorded. This technique, which led to a substantial water contact angle decrease, may thus open up new possibilities in the biomedical field, such as for controlled drug release applications or further post-modification of APs [94-96].

\subsubsection{Factors Influencing Hydrolysis}

There are many factors that can influence AP hydrolysis, which depend on material properties, like chemical composition and molecular architecture, molar mass, polydispersity index, stereochemical structure, chain orientation, polymer morphology, size and shape of specimen, presence of residual monomers, oligomers or other low molecular weight compounds, and on the environment, e.g., temperature, $\mathrm{pH}$, moisture and oxygen level, presence of microorganisms or enzymes, and so on. Among others, crystallinity is undoubtedly the most important factor to be taken into consideration when evaluating polymer degradation rate. Both hydrolysis and enzymatic degradation preferably proceeds in the less packed amorphous regions, which allow for water and enzymes to more easily penetrate in the substrate. Due to the faster degradation of amorphous with respect to crystalline domains, the overall degree of crystallinity increases [88]. Crystallites are also eventually eroded from the edges inward [90]. Recent studies on PBS-based and PBCE-based copolymeric systems containing ether and thioether linkages have clearly demonstrated this phenomenon both for enzymatic [39,93-98] as well as for hydrolytic degradation $[39,99]$ by DSC measurements.

The presence of defects and imperfect crystalline domains plays a role in the degradation rate, as they are usually preferentially degraded together with the amorphous regions [93]. Chain orientation seems to have an effect as well. It has been reported that a higher orientation degree along the fiber axis of PGA sutures slows down the hydrolysis rate [100]. Indeed, when PGA fibers were annealed under clamped conditions, the lateral surface of crystalline regions on the fiber external section, which are very resistant to hydrolysis, remained parallel to the fiber axis thus forming a protective layer preventing water penetration [100]. The porosity of polymer matrix is also a factor. A higher degradation rate has been detected in nonporous films as compared with porous constructs. This effect can be explained taking into account that for porous structures there is no autocatalysis because the ionic exchange is facilitated by the porous structure [101,102]. On the other hand, the enzymatic degradation rate of porous surfaces is faster because of the higher surface/volume ratio. As regards the molar mass is concerned, the lower the polymer molecular weight, the higher the degradation rate, as due to a higher content of carboxylic acid catalyzing groups [89].

Also the influence of $\mathrm{pH}$ on degradation rate has been carefully evaluated. Indeed, ester hydrolysis is highly influenced by $\mathrm{pH}$ variations [103]. In enzymatic degradation, $\mathrm{pH}$ plays an even more important role, due to the close dependence of enzymatic activity on $\mathrm{pH}$ [93]. In this respect, APs biodegradation rate can be tuned, i.e., quickened or reduced, by adding different nanoparticles 
capable of influencing the $\mathrm{pH}$ of the medium, as it has been observed for PCL/layered silicate nanocomposites [103].

Usually, the higher the polymer surface hydrophilicity, the higher the hydrolysis rate due to easier water access. However, in the case of enzymatic degradation, it has been reported that the degradation rate increases when a balanced hydrophobic/hydrophilic ratio is present, due to the enzyme interactions with the polymer surface [94].

In copolymeric systems, there might be a preferential degradation of one copolymeric sequence over the other(s) because of its easier solubilization in water due to a more hydrophilic nature [104]. In this case, changes in molar composition over time, can be easily monitored by $1 \mathrm{H}-\mathrm{NMR}$.

The addition of nanofillers to APs can significantly alter their degradation profile, as due to the modification of the physical and morphological characteristics of the pristine polymer matrix. Composite materials based on inorganic nanoparticles have demonstrated a significant degradation rate increase with respect to the neat polyester [11]. However, different and sometimes contradictory results on the effect of nanoparticles on AP degradation have been reported in the literature. These apparently contradictory results are in our opinion due to the fact that in the analysis of the nanocomposite degradation not only the presence of the nanofillers has to be considered, but additional key points are the chemical properties of the nanofillers, their surface properties (that affect the interface adhesion with the polymer), and the final polymer nanocomposite properties. Some papers reported that nanofillers have an accelerating effect on enzymatic degradation, mainly in nanocomposites based on layered silicate, since hydroxyl groups, which could catalyze the polyester hydrolysis, are present on the edges of the clay. However, other works report that the addition of nanofillers delays the enzymatic degradation of polyesters, because the nanoparticles have high surface volume and act as nucleating agents, thus increasing the degree of crystallinity. During degradation, the crystalline domains are less susceptible to attack, hence the rate of nanocomposite degradation becomes lower as compared to neat polyesters. Furthermore, it must be underlined that the addition of nanoparticles increases the barrier properties of the polyesters, thus reducing water penetration [105].

Nanoparticle surface modification, e.g., achieved through the addition of functional groups, that can not only enhance the compatibility between the polymer matrix and filler, but also influence the degradation rate: for example, the introduction of organically modified layered silicates in PLA matrix resulted in a significant improvement of the hydrolysis rate, as due to the presence of hydroxyl groups of the organic modifier and of the terminal hydroxylated edge groups of the silicate [106].

Also the addition of $\mathrm{COOH}$-functionalized SWCNTs to PLGA matrix contributed to accelerate the hydrolysis kinetic of neat PLGA, due to selective interaction at the interface between nanotubes and polymeric matrix [107]. On the other hand, pristine SWCNTs did not have any effect on the degradation profile of PLGA [107]. Last, but not least, enzyme-filler interactions can play a role in determining the degradation rate. Eker et al. reported on the formation of SWCNTs-proteinase K conjugates that resulted in high enzyme loading due to the large surface area and nanometric size of the SWCNTs [108].

\subsection{Surface Properties}

The surface properties of polymers or polymer nanocomposites are due to unbalanced intermolecular interaction forces or energies across the surface. These forces, which include polar and nonpolar interactions, are also responsible for biomolecular recognition processes. Physical and chemical surface properties of APs and AP-based nanocomposites can be investigated by different techniques. In the following, a brief description of contact angle (CA) measurements and atomic force microscopy (AFM) applied to AP-based nanocomposites are reported. 


\subsubsection{Contact Angle}

CA measurements represent one of the simplest methods to determine changes that take place in the very outer layer of materials. CA is the angle at which a liquid/vapor interface meets a solid surface. By analyzing water CA information on the surface hydrophilicity and hydrophobicity can be gained. CA is a function of the chemical and physical nature of the surface, which depend on the material itself, i.e., its chemical composition, the surface treatment (physical, chemical, and thermal), the surface "history", and the surface cleanliness.

If the selected liquid is very strongly attracted to the sample surface the droplet will completely spread out on the surface, hence the measured contact angle will be very low, less than $10^{\circ}$. Surface with water contact angle until $90^{\circ}$ will be defined as hydrophilic, while surface will be defined hydrophobic, if the water contact angle is higher than $90^{\circ}$, or more in the case of materials with high rough surface that show water $\mathrm{CA}$ greater than $150^{\circ}$, called superhydrophobic surfaces. Furthermore by analyzing the CA of two liquids with completely different properties information on the surface energy can be gathered.

Polymers display a typical water CA that could be modified by chemical and physical methods. Wettability is remarkably affected by the copolymer composition. For example, in the case of PBCE it has been observed a wettability increase with the increasing of BDG co-units content, that is the increment of ether-oxygen atoms along the PBCE backbone [38]. It ranged from $110^{\circ}$ for $\mathrm{PBCE}$, the more hydrophobic material, to $85^{\circ}$ for $\mathrm{P}(\mathrm{BCE} 40 \mathrm{BDG} 60)$. As expected, hydrophilicity regularly increased with the enhancement of the BDG $\mathrm{mol} \%[19,39]$.

The introduction of nanofillers could modify the surface properties of the materials, and further tune the CA. Usually, a hydrophilic surface could better interact with the cell environment. PBCE nanocomposites containing MWCNTs showed in all cases a decrease of the water contact angle with respect to the pristine polymers. These results may be ascribed to the different surface morphology of the samples under investigation, which is affected by the nanofiller introduction, in terms of content, shape, aspect ratio, and processing technology. Through this study it has been possible to demonstrate that the surface wettability is mainly affected by two factors, i.e., the chemical composition and the surface morphology [38].

\subsubsection{Atomic Force Microscopy}

Atomic force microscopy allows us to analyze the materials' surface morphology and to obtain information on its roughness. The AFM is based on a cantilever with a sharp tip at its end, tipically silicon or silicon nitride with a curvature radius of some nanometers. The tip is used to scan the surface of the sample., by using the force between the tip and the sample, and measuring the deflection of the cantilever by monitoring the reflection of a laser. The AFM can be operated in a number of modes, depending on the application: contact, no contact, and tapping.

The atomic force microscope measures topography with a force probe and can achieve a resolution of $10 \mathrm{pm}$ in air and under liquids. AFM permits to analyze organic and inorganic surfaces, giving information on the surface morphology, with atomic resolution in $\mathrm{z}$ and high resolution $(0.1-1 \mu \mathrm{m})$ in $\mathrm{xy}$, under ambient condition, without providing chemical information data. The roughness properties of polymeric samples are mainly due to the processing method used. In the case of solvent casting the mold is the main responsible of the specific surface morphology, then the introduction of nanofillers can increase the surface roughness. The effect is more evident at high nanofiller content or in the case of particle aggregation [12]. 


\subsection{Electrical Properties}

The introduction of conductive nanofillers in an insulator polymer matrix permits to modulate its electrical and dielectrical properties. Electrical properties are mainly investigated by analyzing the bulk conductivity by using a two probe method, or by surface conductivity. The conductivity of a typical polymer, such as APs, is in general less than $10^{-12} \mathrm{ohm}^{-1} \mathrm{~m}^{-1}$, that of semi-insulating or semiconductive materials covers the range $10^{-12}-10 \mathrm{ohm}^{-1} \mathrm{~m}^{-1}$, and for semimetals and metals is greater than $10 \mathrm{ohm}^{-1} \mathrm{~m}^{-1}$. Electrical conduction may occur through the movement of either electrons or ions. The volume resistivity is related to the measured resistance $\mathrm{R}$ between the electrodes by:

$$
\rho_{\mathrm{V}}=\frac{\mathrm{RA}}{1}
$$

where A and 1 are the cross-sectional area and the length of the specimen between the electrodes, respectively.

The main problem in accurate measurement of resistivity is the contact resistance between the measurements electrode and specimens. This is clearly the case of samples with low resistivity. Contact resistance may be reduced by painting electrodes directly on to the surface of the specimen instead of relying on pressure contact with metal plates or foils. Suitable paints are silver dispersions. A much better way to deal with contact resistance is to use a 4-terminal, potentiometric method. The simplest configuration to be used with bulk is that of two current electrodes and two potential electrodes.

The dielectric behavior of a conductive nanocomposite can be analyzed in a different range of frequencies. The complex permittivity of the materials can be viewed in terms of an equivalent parallel circuit, thus the specimen can be represented by a capacitance $C$ in parallel with a Resistance $R$. The total impedance will be given by:

$$
\frac{1}{Z}=\frac{1}{R}+i \omega C
$$

Application of the alternating voltage $(\mathrm{V})$ represented by the real part of $\mathrm{V}$ will produce an out-of-phase or capacitive current $\left(\mathrm{I}_{\mathrm{C}}\right)$ and an in-phase or resistive current $\left(\mathrm{I}_{\mathrm{R}}\right)$.

The analysis of the total impedance of the specimen in different frequency ranges allows for the understanding of the complex relative permittivity and dielectric loss that, in turn allows us to analyze the dielectric relaxation process.

In AP-based nanocomposites it has been observed that the electrical conductivity increased with the CNT introduction and with the CNT weight content with respect to the neat polymer matrix. In fact, CNTs are conductive nanofillers with high aspect ratio: a higher amount of nanotubes create a larger path for the electrical current through the material. This effect is observed in polymers as PLLA, but also in PBCE and its copolymers, and it is mainly due to the CNT network formation, related to the CNT aspect ratio and processing method, which affected the filler dispersion [10-13]. Some differences between the polymers can be observed for lower CNTs loadings, where the effect of the polymer matrix on the overall nanocomposite conductivity seems to be more relevant [10-13]. Dielectric analyses confirmed that the conductive nature is predominant at low frequencies, while at higher frequencies the capacitive behavior provides a constant value for the phase curve [38].

\section{Cells and Polymer-Nanocomposite Interaction}

One of the most important biological application of biomaterials consists on the generation of artificial tissues. "Tissue engineering", is the term coined to identify the "application of principles and methods of engineering and life sciences toward the fundamental understanding of structure-function relationships in normal and pathological mammalian tissues and the development of biological substitutes to restore, maintain, or improve tissue function" as officially declared at the National Science Foundation workshop in 1988 [1-5]. 


\subsection{Stem Cells and Differentiated Cells}

The production of the engineered tissue needs the use of a proper cell type that populate the substrate and gives rise to a tissue resembling the native one. Initially, primary cells taken from the patients or healthy donors were used in combination with scaffolds to generate artificial tissue for implantation. Scaffolds have to provide adequate physical and chemical characteristics to guide cell adhesion, migration, and differentiation and support new tissue formation. The scaffolds should have an interconnected 3D morphology with micro and nanoporosities that can guarantee cell migration and nutrient flow. The chemical properties of the scaffold's material are important, as well as its 3D morphology. Polymers are the main used materials for scaffold fabrication; however the use of nanocomposite materials can be the ideal approach in order to develop 3D structures with modulated mechanical, thermal, and morphological properties.

Now, the knowledge on stem cell biology and on their therapeutic potentials [109-111] steers the focus to stem cells as a suitable source for tissue engineering. In particular it is largely demonstrated that stem cells specifically respond to the characteristics of the biomaterials changing shape, adhesion property, and mainly, their phenotype [112-126]. Many types of stem cells, such as embryonic stem cells, bone-marrow mesenchymal stem cells, adipose stem cells, umbilical cord-derived mesenchymal stem cells, and induced pluripotent stem cells have been explored [127,128]. For instance, multipotent mesenchymal cells (derived either from bone marrow and adipose tissue) based on their capability to differentiate into multiple cell lineages such as osteocytes, adipocytes, and chondrocytes are often combined with three-dimensional scaffolds to reestablish the defects of the osteogenic or adipogenic tissues [10,71,129-131] (Table 2).

In a tissue engineering system, to be effective the material has to guarantee cell viability, adhesion, morphology, and differentiation. In this section, the methods that allow the study of the above-mentioned parameters are described.

\subsection{Cell Viability}

The first characteristic of the material must be the biocompatibility, as the construct have to maintain cell viability as well as cell properties and functions. Several commercial assays can be adopted to verify the absence of cell toxicity [131,132]. For instance, 3-[4-dimethylthiazol-2-yl]-2,5-diphenyltetrazolium bromide yields a yellow solution when prepared in buffer or tissue culture without phenol red, whose concentration can be measured in a spectrophotometer. Of note, only viable cells metabolize the tetrazolium salt to formazan by the mitochondrial dehydrogenase enzymes. Therefore, the concentration of produced formazan dye gives the direct indication of the number of metabolically active cells in the culture [133,134]. The formazan is then dissolved in dimethylsulfoxide (DMSO) and its concentration is determined by the spectrophotometer. Alternatively to MTT is the product of 2,3-bis-(2-methoxy-4-nitro-5-sulphenyl)-(2H)-tetrazolium-5-carboxanilide (XTT Cell Proliferation Assays) that is soluble in water [12,135].

\subsection{Cell Adhesion}

The polymer construct must be able to support cell adhesion. Within the tissues, the maintaining of their structure and function is guaranteed also by cell adhesion. This activity is accomplished by the focal adhesion proteins, a large complex that assemblies through mechanical force and regulatory signals and connects the extracellular matrix with the cell [136-141]. The molecular adhesion of the cells on a biomaterial can be studied by monitoring the focal adhesion proteins such as Cadherins and Vinculin. Cadherins are a class of proteins that is differentially expressed during the differentiation process, such as in embryonic development and the nervous system [10]. These proteins have distinct temporal and spatial localization. The family of Cadherins include E-cadherins (typically expressed in epithelial cells), P-cadherins (typically expressed in placental), $\mathrm{N}$-cadherins (typically expressed 
in neural cells), B-cadherins and T-cadherins (brain), and M-cadherins (muscle) [142,143]. Vinculin is a cytoskeletal protein associated with cell-cell and cell-matrix junctions, where it is thought to function as one of several interacting proteins involved in anchoring F-actin to the membrane [144,145]. The immunofluorescence technique is the gold standard for visualizing the adhesion of cells on biomaterial surfaces. Briefly, immunofluorescence combines fluorescence microscopy with the specificity of antibodies toward the antigen. The complex antibodies-antigen is then revealed by a fluorescent dye that is conjugated with the antibody. The fluorescent signal is captured by the fluorescence microscope. This technique has been widely adopted to reveal the focal adhesion spots. For instance, by using this procedure we have revealed the focal adhesion spots at the interface of human bone-marrow- mesenchymal stem cells and film of uniform hydrogenated amorphous carbon or a film of hydrogenated amorphous carbon with a groove, or grid nanopatterns [146].

Table 2. Biological effects of poly-L-lactide (PLLA) polymer in different form (electrospun fibers and film), in combination with different nanofillers [hydroxyapatite (HAP) or multiwalled carbon nanotubes (MWCNTs)] or after oxygen $\left(\mathrm{O}_{2}\right)$ modification in different stem cell types.

\begin{tabular}{cccc}
\hline Stem Cell Types & Biomaterial & Differentiation & Ref. \\
\hline hBMSCs & Electrospun PLLA & No differentiation (stemness maintenance) & {$[72]$} \\
iPSCs & Electrospun PLLA + HAP & Osteogenic & {$[65]$} \\
ESCs & Film PLLA & Epiblast-like & {$[10]$} \\
\multirow{2}{*}{ hUCMSCs } & Film PLLA + MWCNTs & Primitive endoderm-like & {$[10]$} \\
& Film PLLA + O & Acquisition of spheroids conformation & {$[10,147]$} \\
\hline \multirow{2}{*}{ hASCs } & Film PLLA & Morphology maintenance & {$[147]$} \\
& Film PLLA + $\mathrm{O}_{2}$ & Acquisition of spheroids conformation & {$[147]$} \\
\hline
\end{tabular}

\subsection{Cell Morphology}

Cell morphology studies allow for the identification of the shape, structure, and size of cells. Therefore, the regular examination of the cell morphology in culture is mandatory for a successful cell culture on biomaterials within a bio-hybrid system. The cell shape might be evaluated by using several commercial reagents that label cell membranes without affecting cell viability, such as the Lipophilic Tracers or Carbocyanine dyes [147]. The cytoskeleton architecture is directly correlated with the cell morphology. Therefore, the visualization of the F-actin filaments or the microtubules organization gives good indication of the form of the cells seeded on biomaterials. Thus, Phalloidin is a toxin belonging to a class of phallotoxins, found in the mushroom Amanita phalloides, that attack the host cells by a tight and selective binding with the F-actin filaments. On this basis, commercially available phalloidin containing fluorescent tags might be used to visualize F-actin widely with fluorescent microscopy [148]. Cytoplasmic microtubules can be visualized by indirect immunofluorescence staining of chemically fixed cells with tubulin antibody-conjugated with a fluorescent dye by using a fluorescence microscopy $[137,149]$.

The staining of F-actin and microtubules of cells seeded on biomaterials might be used to define the cell shape index [150]. This parameter is useful to establish if the biomaterial affects or influences the morphology of the cells.

In order to investigate the cells morphology, scanning electron microscopy (SEM) is also used. SEM produces images by probing the sample with a focused electron beam that is scanned across the area of the specimen. During the interaction, the electron beam loses energy by a variety of mechanisms, converting it into alternative forms, which provide signals carrying information about the properties of the specimen surface, such as its topography and composition. SEM is able to image bulk samples up to many centimeters in size and has a great depth of field. Therefore, it can produce images that are good representations of the three-dimensional shape of the sample. SEM has improved resolution capacities with respect to the optical microscope, high depth of focus, simplified interpretation of the images due to the 3D impression, and use of different contrast mechanisms for the creation of images. 
One of the major problems with the use of SEM on biological materials is the sample preparation. Since the SEM operates in high vacuum levels, biological samples must be dehydrated before the analysis. Furthermore, the deposition of a conductive layer on the sample reduces thermal damage, inhibits charging, and improves the secondary electron signal required for SEM analysis.

As an example of the application of the above investigation tools, is the evaluation of the morphology of different types of stem cells (human adult adipose stem cells (hASCs), human bone-marrow mesenchymal stem cells (hBM-MSCs), and human umbilical matrix stem cells (hUCMSCs) seeded on the surface of PLLA polymer film [151]. This work was conducted to explore the effects of the interaction at interface of human stem cells and PLLA polymer films, and in turn to improve our previous studies that had demonstrated the molecular cross-talk between stem cells and PLLA nanocomposites on guiding the stem cells fate $[10,12]$. Briefly, the above stem cell types were seeded on films of pristine PLLA polymer and on film of PLLA with their surface modified by the radiofrequency plasma method under oxygen flow $\left(\mathrm{PLLA}+\mathrm{O}_{2}\right)$. As a consequence of the treatment the surface of PLLA films became hydrophilic, whereas the bulk properties of the polymer film were not affected. The analysis of the cytoskeleton, by the specific staining of F-actin with FITCH-Phalloidin, demonstrated that while hASCs cultured on pristine PLLA polymer films acquired a spheroid conformation, the hASCs seeded on PLLA $+\mathrm{O}_{2}$ film surface kept the fibroblast-like morphology classically observed on tissue culture polystyrene. These data suggested that the surface hydrophilicity is involved in the acquisition of the spheroid conformation of adipose stem cells. Moreover, the cytoskeleton staining permitted to demonstrate that the oxygen treatment had no effect on the other two type of stem cell (hBM-MSCs and hUCMSCs) cultures seems both stem cells maintained the same shape observed on PLLA films [150]. (Table 2).

In another work, the same procedure was employed to study the interaction of primary cells on multifunctional nanocomposites of PBCE-based copolyesters and single walled carbon nanotubes [38].

\subsection{Cell Differentiation}

To be successful, tissue engineering must guarantee the correct function of the cells. This includes the stem cell properties, the stem cell specification process, and their differentiation. The different cell status is strictly correlated with the final application of the tissue engineering biohybrid system $[4,10,151]$. In particular, cell differentiation, as the process through committed progenitor cells evolves toward a specialized cell reaching its mature form and function, represents a goal standard of the tissue engineering. (Table 2)

Currently, the biological status of a cell might be evaluated with many innovative strategies that give a landscape information about the genes and proteins expressed in a given cell type, such as the genome-wide gene expression profiling or the proteome-wide expression profiling [152-154]. Alternatively, as stem, committed and differentiated cells are specifically correlated to a biological function, the monitoring of the correct status might be studied by evaluating a more restricted number of genes and proteins. In fact, as these molecules are specifically expressed in a type of cell with a specific phenotype (e.g., stem cells, committed, and differentiated), they are considered as the identification markers to be monitored. In this case, techniques as real-time polymerase chain reaction (Real-Time PCR or qPCR) (to measure the gene expression), Western blotting (to measure the expression of proteins), and the immunofluorescence (to visualize the proteins into the cells) might be helpful to evaluate the expression of such markers.

Western blotting is a broadly analytical technique used to identify specific proteins in a biological sample, based on the capability of antibodies to react with a specific target protein. Then, the complex target protein-antibody is detected by a secondary antibody conjugated with a dye or an enzyme that may be easily measured.

Real-Time PCR measures the amplification of a DNA target during the procedure. Generally, the template is the cDNA obtained by the purified and retro-transcribed mRNAs of given cells (e.g., cells cultured on a biomaterial). 
Immunofluorescences and colorimetric staining for monitoring specific differentiation markers are also helpful for addressing the changes of phenotype of cells cultured on biomaterials. For instance, Alizarin Red S and Von Kossa staining are classical assays for evaluating the osteogenic differentiation [65], whereas the Oil Red staining is the most useful assay for evaluating the audiogenic differentiation process [65].

The above-mentioned techniques were, for example, used to investigate the effect of nanocomposite fibrous materials of PLLA loaded with 1 or $8 \mathrm{wt} \%$ of calcium-deficient nanohydroxyapatite (d-HAp) on human-bone-marrow-derived mesenchymal stem cells, murine-induced pluripotent stem cells, and murine embryonic stem cells. The d-Hap incorporated in the PLLA polymer matrix by electrospinning consisted of needle-like particles, with width of 10-30 nm and length of 50-100 nm. We have demonstrated that the culture of the above-mentioned stem cell types on PLLA/d-HAp nanocomposites in the absence of soluble osteogenic factors induced the expression of the osteogenic markers. This differentiation process was absent on all stem cell types grown on neat PLLA cultures [71].

The techniques described in this review allowed us to demonstrate that the active interaction between the human umbilical cord matrix stem cells and PLLA and PLLA/Multi Walled Carbon Nanotubes (MWCNTs) nanocomposite films, resulted in the stem cell acquisition of a spheroid conformation and in the transition of the stem cell fate. For instance, the F-actin staining allowed to visualize the spheroids conformation of the cells and how they directly respond to the surface and the bulk properties (e.g., electric, dielectric, and thermal) of neat and nanocomposite PLLA films (mechanotransduction axis). Moreover, the expression of specific makers permitted to correlate the stem cell-biomaterial interaction with the stem cells status. In particular, the opposite expression of the transcription factors NANOG and GATA6, together with the other proteins related to the same lineage specification process, demonstrated that spheroids express an Epiblast-like phenotype on PLLA and a Primitive Endoderm-like lineage commitment on PLLA/1 wt \% MWCNTs [10].

Similarly, the above procedures were adopted to determine that the design of groove nanotopography with width/spacing ridges of $40 / 30 \mu \mathrm{m}$ and depth of $24 \mathrm{~nm}$ on the surface of hydrogenated amorphous carbon induced human bone-marrow mesenchymal stem cells to acquire a neuronal-like phenotype in the absence of neuronal differentiating agents [155].

Another example come from a study that we conducted by using electrospun scaffolds fabricated with a new class of block poly(butylene succinate)-based (PBS-based) copolyesters containing either butylene thiodiglycolate (BTDG) or butylene diglycolate (BDG) sequences. The results of the interaction with human mesenchymal stromal cells (hMSCs) demonstrated the hold potential of these functional scaffold in osteochondral tissue engineering applications. In particular, PBS-based copolyesters containing thio-ether linkages (i.e., BTDG segments) were more favorable for chondrogenesis of hMSCs than those containing ether linkages (i.e., BDG sequences). In contrast, PBS-based copolyesters containing ether linkages showed enhanced mineralization. The presence of BTDG units in the copolymers demonstrated a better support of chondrogenic differentiation of hMSCs with respect to BDG co-units. Furthermore, the same chemical composition, but a different molecular architecture (i.e., blend or block copolymer) highlighted a very different effect on hMSCs [106]. Very recently, it has been demonstrated that an increased amount of ether bonds along the backbone of poly(butylene succinate)-based scaffolds is able to promote the biological interaction. This is due to a higher density of hydrogen bonds acceptors that can favor cell attachment on the polymer matrix as well as nanofiber alignment, beneficial for cell contact guidance and proliferation [156].

\subsection{Mechanotransduction}

As described above, mechanotransduction is referred to all the molecular pathways that are activated in the stem cells as specific response to the chemical-physical properties of the biomaterial used for generating a biohybrid system (cells + biomaterial) [157-170]. Biomaterials can have effects on a given cell type at different levels, such as oncell morphology, proliferation, cytoskeleton architecture, 
gene expression, and differentiation. The microenvironment was shown to be essential in cell lineage specification [159]. In particular, the mechanical properties of the substrates were correlated to direct specific lineage, without strongly perturbing many other aspects of cell function and shape [157].

Therefore, evaluation of these molecular mechanisms includes all the biological techniques that are documented above $[10,65,126,157]$. In addition, physical and chemical investigations are also necessary in order to correlate the biological changes with the characteristic of the materials $[10-15,38,157]$.

\section{Conclusions and Future Perspective}

This contribution represents an overview of the available routes for the preparation of APs-based nanocomposites showing suitable characteristics with respect to the intended biomedical application. Not only the choice of the starting materials, i.e., polymer matrix and filler, plays an important role, yet also the polymer synthetic strategies adopted and the nanocomposite processing technology are of crucial importance for the development of materials with tailored functional properties. It has been indeed demonstrated that different polymerization and copolymerization approaches can be adopted to modify the physicochemical properties of APs that, in turn, determine the processing conditions for the nanocomposite fabrication, e.g., solvent selection for casting procedures or optimal temperature(s) for melt mixing.

Besides good filler/matrix compatibility, homogenous dispersion is highly desirable for the nanoparticles to exert the desired functions, which can range from nucleation ability, to enhanced thermal stability, increased surface wettability, or electrical conductivity.

All these properties have then a significant impact on the hydrolysis rate of the nanocomposites and on their biological response in terms of cell attachment and proliferation, morphology, and differentiation ability.

However, although much research has been conducted and important discoveries have been made in this field, further studies are necessary to fully comprehend the actual applicability and marketability of APs-based nanocomposites in biomedicine.

Last but not least, the realization of suitable constructs not only capable of supporting, yet also of favoring cell attachment and proliferation, is of crucial importance. In this framework, 3D printing may represent an innovative and valuable processing technique for the development of 3D scaffolds from AP-based nanocomposites.

Funding: This research was funded by M-ERANET Project "POLYMAGIC".

Conflicts of Interest: The authors declare no conflicts of interest.

\section{References}

1. Nerem, R.M. Tissue engineering in the USA. Med. Biol. Eng. Comput. 1992, 30, CE8-CE12. [CrossRef] [PubMed]

2. McGovern, J.A.; Griffin, M.; Hutmacher, D.W. Animal models for bone tissue engineering and modelling disease. Dis. Model. Mech. 2018, 11, dmm033084. [CrossRef] [PubMed]

3. Atala, A. Tissue engineering and regenerative medicine: Concepts for clinical application. Rejuvenation Res. 2004, 7, 15-31. [CrossRef] [PubMed]

4. Oryan, A.; Alidadi, S.; Moshiri, A.; Bigham-Sadegh, A. Bone morphogenetic proteins: A powerful osteoinductive compound with non-negligible side effects and limitations. Biofactors 2014, 40, 459-481. [CrossRef] [PubMed]

5. Lutolf, M.P.; Gilbert, P.M.; Blau, H.M. Designing materials to direct stem-cell fate. Nature 2009, 462, 433-441. [CrossRef] [PubMed]

6. Ulery, B.D.; Nair, L.S.; Laurencin, C.T. Biomedical applications of biodegradable polymers. J. Polym. Sci. Part B Polym. Phys. 2011, 49, 832-864. [CrossRef] [PubMed]

7. Vilela, C.; Sousa, A.F.; Fonseca, A.C.; Serra, A.C.; Coelho, J.F.J.; Freirea, C.S.R.; Silvestre, A.J.D. The quest for sustainable polyesters-Insights into the future. Polym. Chem. 2014, 5, 3119-3141. [CrossRef] 
8. Díaz, A.; Katsarava, R.; Puiggalí, J. Synthesis, Properties and Applications of Biodegradable Polymers Derived from Diols and Dicarboxylic Acids: From Polyesters to Poly(ester amide)s. Int. J. Mol. Sci. 2014, 15, 7064-7123. [CrossRef] [PubMed]

9. Zia, K.M.; Noreen, A.; Zuber, M.; Tabasum, S.; Mujahid, M. Recent developments and future prospects on bio-based polyesters derived from renewable resources: A review. Int. J. Biol. Macromol. 2016, 82, 1028-1040. [CrossRef] [PubMed]

10. Morena, F.; Armentano, I.; Montanucci, P.; Argentati, C.; Fortunati, E.; Montesano, S.; Bicchi, I.; Pescara, T.; Pennoni, I.; Mattioli, S.; et al. Design of a nanocomposite substrate inducing adult stem cell assembly and progression toward an Epiblast-like or Primitive Endoderm-like phenotype via mechanotransduction. Biomaterials 2017, 144, 211-229. [CrossRef] [PubMed]

11. Armentano, I.; Dottori, M.; Fortunati, E.; Mattioli, S.; Kenny, J.M. Biodegradable polymer matrix nanocomposites for tissue engineering: A review. Polym. Degrad. Stab. 2010, 95, 2126-2146. [CrossRef]

12. Lizundia, E.; Sarasua, J.R.; D'Angelo, F.; Orlacchio, A.; Martino, S.; Kenny, J.M.; Armentano, I. Biocompatible poly(L-lactide)/MWCNT nanocomposites: Morphological characterization, electrical properties, and stem cell interaction. Macromol. Biosci. 2012, 12, 870-881. [CrossRef] [PubMed]

13. Fortunati, E.; Gigli, M.; Luzi, F.; Lotti, N.; Munari, A.; Gazzano, M.; Armentano, I.; Kenny, J.M. Poly(butylene cyclohexanedicarboxylate/diglycolate) random copolymers reinforced with SWCNTs for multifunctional conductive biopolymer composites. Express Polym. Lett. 2016, 10, 111-124. [CrossRef]

14. Fortunati, E.; Gigli, M.; Luzi, F.; Dominici, F.; Lotti, N.; Gazzano, M.; Cano, A.; Chiralt, A.; Munari, A.; Kenny, J.M.; et al. Processing and characterization of nanocomposite based on poly (butylene/triethylene succinate) copolymers and cellulose nanocrystals. Carbohydr. Polym. 2017, 165, 51-60. [CrossRef] [PubMed]

15. Lizundia, E.; Fortunati, E.; Dominici, F.; Vilas, J.L.; León, L.M.; Armentano, I.; Torre, L.; Kenny, J.M. PLLA-grafted cellulose nanocrystals: Role of the CNC content and grafting on the PLA bionanocomposite film properties. Carbohydr. Polym. 2016, 142, 105-113. [CrossRef] [PubMed]

16. Murariu, M.; Dubois, P. PLA composites: From production to properties. Adv. Drug Deliv. Rev. 2016, 107, 17-46. [CrossRef] [PubMed]

17. Zhang, M.; Thomas, N.L. Blending polylactic acid with polyhydroxybutyrate: The effect on thermal, mechanical, and biodegradation properties. Adv. Polym. Technol. 2011, 30, 67-79. [CrossRef]

18. Gigli, M.; Fabbri, M.; Lotti, N.; Gamberini, R.; Rimini, B.; Munari, A. Poly(butylene succinate)-based polyesters for biomedical applications: A review. Eur. Polym. J. 2016, 75, 431-460. [CrossRef]

19. Gigli, M.; Lotti, N.; Gazzano, M.; Siracusa, V.; Finelli, L.; Munari, A.; Della Rosa, M. Fully Aliphatic Copolyesters Based on Poly(butylene 1,4-cyclohexanedicarboxylate) with Promising Mechanical and Barrier Properties for Food Packaging Applications. Ind. Eng. Chem. Res. 2013, 52, 12876-12886. [CrossRef]

20. Flory, P.J. Molecular Size Distribution in Linear Condensation Polymers. J. Am. Chem. Soc. 1936, 58, 1877-1885. [CrossRef]

21. Flory, P.J. Kinetics of Polyesterification: A Study of the Effects of Molecular Weight and Viscosity on Reaction Rate. J. Am. Chem. Soc. 1939, 61, 3334-3340. [CrossRef]

22. Flory, P.J. Constitution of three-dimensional polymers and the theory of gelation. J. Phys. Chem. 1942, 46, 132-140. [CrossRef]

23. Flory, P.J. Thermodynamics of Crystallization in High Polymers II. Simplified Derivation of Melting-Point Relationships. J. Chem. Phys. 1947, 15, 684. [CrossRef]

24. Kats, A.R.; Turner, R. Evaluation of tensile and absorption properties of polyglycolide sutures. J. Surg. Gynecol. Obstet. 1970, 131, 701-716.

25. Gunatillake, P.; Mayadunne, R.; Adhikari, R. Recent developments in biodegradable synthetic polymers. Biotechnol. Annu. Rev. 2006, 12, 301-347. [CrossRef] [PubMed]

26. Farah, S.; Anderson, D.G.; Langer, R. Physical and mechanical properties of PLA, and their functions in widespread applications-A comprehensive review. Adv. Drug Deliv. Rev. 2016, 107, 367-392. [CrossRef] [PubMed]

27. Ramot, Y.; Haim-Zada, M.; Domb, A.J.; Nyska, A. Biocompatibility and safety of PLA and its copolymers. Adv. Drug Deliv. Rev. 2016, 107, 153-162. [CrossRef] [PubMed]

28. Labet, M.; Thielemans, W. Synthesis of polycaprolactone: A review. Chem. Soc. Rev. 2009, 38, 3484-3504. [CrossRef] [PubMed] 
29. Ceccarelli, G.; Presta, R.; Lupi, S.M.; Giarratana, N.; Bloise, N.; Benedetti, L.; Cusella De Angelis, M.G.; Rodriguez, Y.; Baena, R. Evaluation of Poly(Lactic-co-glycolic) Acid Alone or in Combination with Hydroxyapatite on Human-Periosteal Cells Bone Differentiation and in Sinus Lift Treatment. Molecules 2017, 22, 2109. [CrossRef] [PubMed]

30. Rodriguez, Y.; Baena, R.; D’Aquino, R.; Graziano, A.; Trovato, L.; Aloise, A.C.; Ceccarelli, G.; Cusella, G.; Pelegrine, A.A.; Lupi, S.M. Autologous Periosteum-Derived Micrografts and PLGA/HA Enhance the Bone Formation in Sinus Lift Augmentation. Front. Cell Dev. Biol. 2017, 5, 87. [CrossRef] [PubMed]

31. Dash, T.K.; Konkimalla, V.B. Poly- $\epsilon$-caprolactone based formulations for drug delivery and tissue engineering: A review. J. Control. Release 2012, 158, 15-33. [CrossRef] [PubMed]

32. Qazi, T.H.; Mooney, D.J.; Pumberger, M.; Geißler, S.; Duda, G.N. Biomaterials based strategies for skeletal muscle tissue engineering: Existing technologies and future trends. Biomaterials 2015, 53, 502-521. [CrossRef] [PubMed]

33. Stefani, I.; Cooper-White, J.J. Development of an in-process UV-crosslinked, electrospun PCL/aPLA-co-TMC composite polymer for tubular tissue engineering applications. Acta Biomater. 2016, 36, 231-240. [CrossRef] [PubMed]

34. Amache, R.; Sukan, A.; Safari, M.; Roy, I.; Keshavarz, T. Advances in PHAs Production. Chem. Eng. Trans. 2013, 32, 931-936. [CrossRef]

35. Abe, H.; Doi, Y. Structural effects on enzymatic degradabilities for poly[(R)-3-hydroxybutyric acid] and its copolymers. Int. J. Biol. Macromol. 1999, 25, 185-192. [CrossRef]

36. Laeger, T.; Metges, C.C.; Kuhla, B. Role of $\beta$-hydroxybutyric acid in the central regulation of energy balance. Appetite 2010, 54, 450-455. [CrossRef] [PubMed]

37. Xu, J.; Guo, B.H. Poly(butylene succinate) and its copolymers:Research, development and industrialization. Biotechnol. J. 2010, 5, 1149-1163. [CrossRef]

38. Armentano, I.; Fortunati, E.; Gigli, M.; Luzi, F.; Trotta, R.; Bicchi, I.; Soccio, M.; Lotti, N.; Munari, A.; Martino, S.; et al. Effect of SWCNT introduction in random copolymers on material properties and fibroblast long term culture stability. Polym. Degrad. Stab. 2016, 132, 220-230. [CrossRef]

39. Gigli, M.; Lotti, N.; Vercellino, M.; Visai, L.; Munari, A. Novel ether-linkages containing aliphatic copolyesters of poly(butylene 1,4-cyclohexanedicarboxylate) as promising candidates for biomedical applications. Mater. Sci. Eng. C 2014, 34, 86-97. [CrossRef] [PubMed]

40. Gigli, M.; Govoni, M.; Lotti, N.; Giordano, E.D.; Gazzano, M.; Munari, A. Biocompatible multiblock aliphatic polyesters containing ether-linkages: Influence of molecular architecture on solid-state properties and hydrolysis rate. RSC Adv. 2014, 4, 32965-32976. [CrossRef]

41. Pang, K.; Kotek, R.; Tonelli, A. Review of conventional and novel polymerization processes for polyesters. Prog. Polym. Sci. 2006, 31, 1009-1037. [CrossRef]

42. Jérôme, C.; Lecomte, P. Recent advances in the synthesis of aliphatic polyesters by ring-opening polymerization. Adv. Drug Deliv. Rev. 2008, 60, 1056-1076. [CrossRef] [PubMed]

43. Varma, K.; Albertsson, A.C.; Rajkhowa, R.; Srivastava, R.K. Enzyme catalyzed synthesis of polyesters. Prog. Polym. Sci. 2005, 30, 949-981. [CrossRef]

44. Okada, M. Chemical syntheses of biodegradable polymers. Prog. Polym. Sci. 2002, 27, 87-133. [CrossRef]

45. Latere Dwan'Isa, J.-P.; Lecomte, P.; Dubois, P.; Jérôme, C. Synthesis and Characterization of Random Copolyesters of $\varepsilon$-Caprolactone and 2-Oxepane-1,5-dione. Macromolecules 2003, 36, 2609-2615. [CrossRef]

46. Odent, J.; Leclère, P.; Raquez, J.-M.; Dubois, P. Toughening of polylactide by tailoring phase-morphology with P[CL-co-LA] random copolyesters as biodegradable impact modifiers. Eur. Polym. J. 2013, 49, 914-922. [CrossRef]

47. Hu, X.; Zeng, J.; Dai, W.; Shi, W.; Li, L.; Han, C. EPDM/vinyl triethoxysilane modified phenol formaldehyde resin composite. Polym. Bull. 2011, 66, 703-710. [CrossRef]

48. Raquez, J.-M.; Narayan, R.; Dubois, P. Recent Advances in Reactive Extrusion Processing of Biodegradable Polymer-Based Compositions. Macromol. Mater. Eng. 2008, 293, 447-470. [CrossRef]

49. Liu, N.C.; Baker, W.E. Reactive polymers for blend compatibilization. Adv. Polym. Technol. 1992, 11, $249-262$. [CrossRef]

50. Gigli, M.; Lotti, N.; Gazzano, M.; Finelli, L.; Munari, A. Synthesis and characterization of novel poly(butylene succinate)-based copolyesters designed as potential candidates for soft tissue engineering. Polym. Eng. Sci. 2013, 53, 491-501. [CrossRef] 
51. Soccio, M.; Lotti, N.; Gigli, M.; Finelli, L.; Gazzano, M.; Munari, A. Reactive blending of poly(butylene succinate) and poly(triethylene succinate): Characterization of the copolymers obtained. Polym. Int. 2012, 61, 1163-1169. [CrossRef]

52. Gigli, M.; Lotti, N.; Siracusa, V.; Gazzano, M.; Munari, A.; Dalla Rosa, M. Effect of molecular architecture and chemical structure on solid-state and barrier properties of heteroatom-containing aliphatic polyesters. Eur. Polym. J. 2016, 78, 314-325. [CrossRef]

53. Fabbri, M.; Soccio, M.; Gigli, M.; Guidotti, G.; Gamberini, R.; Gazzano, M.; Siracusa, V.; Rimini, B.; Lotti, N.; Munari, A. Design of fully aliphatic multiblock poly(ester urethane)s displaying thermoplastic elastomeric properties. Polymer 2016, 83, 154-161. [CrossRef]

54. Genovese, L.; Soccio, M.; Gigli, M.; Lotti, N.; Gazzano, M.; Siracusa, V.; Munari, A. Gas permeability, mechanical behaviour and compostability of fully-aliphatic bio-based multiblock poly(ester urethane)s. RSC Adv. 2016, 6, 55331-55342. [CrossRef]

55. Fabbri, M.; Gigli, M.; Gamberini, R.; Lotti, N.; Gazzano, M.; Rimini, B.; Munari, A. Hydrolysable PBS-based poly(ester urethane)s thermoplastic elastomers. Polym. Degrad. Stab. 2014, 108, 223-231. [CrossRef]

56. Wang, J.; Zheng, L.; Li, C.; Zhu, W.; Zhang, D.; Guan, G.; Xiao, Y. Synthesis and Properties of Biodegradable Poly(ester-co-carbonate) Multiblock Copolymers Comprising of Poly(butylene Succinate) and Poly(butylene Carbonate) by Chain Extension. Ind. Eng. Chem. Res. 2012, 51, 10785-10792. [CrossRef]

57. Merlettini, A.; Gigli, M.; Ramella, M.; Gualandi, C.; Soccio, M.; Boccafoschi, F.; Munari, A.; Lotti, N.; Focarete, M.L. Thermal Annealing to Modulate the Shape Memory Behavior of a Biobased and Biocompatible Triblock Copolymer Scaffold in the Human Body Temperature Range. Biomacromolecules 2017, 18, 2499-2508. [CrossRef] [PubMed]

58. Dresselhaus, M.S.; Dresselhaus, G.; Eklund, P.C. Science of Fullerenes and Carbon Nanotubes: Their Properties and Applications; Academic Press: San Diego, CA, USA, 1996.

59. Iijima, S. Helical microtubules of graphitic carbon. Nature 1991, 354, 56-58. [CrossRef]

60. Iijima, S.; Ichihashi, T. Single-shell carbon nanotubes of 1-nm diameter. Nature 1993, 363, 603-605. [CrossRef]

61. Geim, A.K.; Novoselov, K.S. The rise of graphene. Nat. Mater. 2007, 6, 183-191. [CrossRef] [PubMed]

62. Lacerda, L.; Bianco, A.; Prato, M.; Kostarelos, K. Carbon nanotubes as nanomedicines: From toxicology to pharmacology. Adv. Drug Deliv. Rev. 2006, 58, 1460-1470. [CrossRef] [PubMed]

63. Trache, D.; Hazwan Hussin, M.; Mohamad Haafizc, M.K.; Thakur, V.K. Recent progress in cellulose nanocrystals: Sources and production. Nanoscale 2017, 9, 1763-1786. [CrossRef] [PubMed]

64. Fortunati, E.; Mattioli, S.; Visai, L.; Imbriani, M.; Fierro, J.L.G.; Kenny, J.M.; Armentano, I. Combined effects of Ag Nanoparticles and Oxygen Plasma Treatments on PLGA Morphological, Chemical, and Antibacterial Properties. Biomacromolecules 2013, 14, 626-636. [CrossRef] [PubMed]

65. D'Angelo, F.; Armentano, I.; Cacciotti, I.; Tiribuzi, R.; Quattrocelli, M.; Del Gaudio, C.; Fortunati, E.; Saino, E.; Caraffa, A.; Cerulli, G.G.; et al. Tuning Multi/Pluri-Potent Stem Cell Fate by Electrospun Poly(l-lactic acid)-Calcium-Deficient Hydroxyapatite Nanocomposite Mats. Biomacromolecules 2012, 13, 1350-1360. [CrossRef] [PubMed]

66. Puglia, D.; Ceccolini, R.; Fortunati, E.; Armentano, I.; Morena, F.; Martino, S.; Aluigi, A.; Torre, L.; Kenny, J.M. Effect of processing techniques on the 3D microstructure of poly (L-lactic acid) scaffolds reinforced with wool keratin from different sources. J. Appl. Polym. Sci. 2015, 132, 42890. [CrossRef]

67. Ojijo, V.; Ray, S.S. Processing strategies in bionanocomposites. Prog. Polym. Sci. 2013, 38, $1543-1589$. [CrossRef]

68. Mattioli, S.; Kenny, J.M.; Armentano, I. Plasma surface modification of porous PLLA films: Analysis of surface properties and in-vitro hydrolytic degradation. J. Appl. Polym. Sci. 2012, 125, E239-E247. [CrossRef]

69. Armentano, I.; Bitinis, N.; Fortunati, E.; Mattioli, S.; Rescignano, N.; Verdejo, R.; Lopez-Manchado, M.A.; Kenny, J.M. Multifunctional nanostructured PLA materials for packaging and tissue engineering. Prog. Polym. Sci. 2013, 38, 1720-1747. [CrossRef]

70. Raquez, J.M.; Habibi, Y.; Murariu, M.; Dubois, P. Polylactide (PLA)-based nanocomposites. Prog. Polym. Sci. 2013, 38, 1504-1542. [CrossRef]

71. Bianco, A.; Bozzo, B.M.; Del Gaudio, C.; Cacciotti, I.; Armentano, I.; Dottori, M.; D’Angelo, F.; Martino, S.; Orlacchio, A.; Kenny, J.M. Poly (L-lactic acid)/calcium-deficient nanohydroxyapatite electrospun mats for bone marrow stem cell cultures. J. Bioact. Compat. Polym. 2011, 26, 225-241. [CrossRef] 
72. Ciapetti, G.; Granchi, D.; Devescovi, V.; Baglio, S.R.; Leonardi, E.; Martini, D.; Jurado, J.M.; Olalde, B.; Armentano, I.; Kenny, J.M.; et al. Enhancing Osteoconduction of PLLA-Based Nanocomposite Scaffolds for Bone Regeneration Using Different Biomimetic Signals to MSCs. Int. J. Mol. Sci. 2012, 13, 2439-2458. [CrossRef] [PubMed]

73. Armentano, I.; Dottori, M.; Fortunati, E.; Villareal, E.; Chàvez, J.L.; Arzate, H.; Kenny, J.M. Development of PLGA nanocomposite films and scaffolds for bone tissue engineering. J. Nanostruct. Polym. Nanocompos. 2012, 8, 12-20.

74. Gigli, M.; Lotti, N.; Gazzano, M.; Siracusa, V.; Finelli, L.; Munari, A.; Dalla Rosa, M. Biodegradable aliphatic copolyesters containing PEG-like sequences for sustainable food packaging applications. Polym. Degrad. Stab. 2014, 105, 96-106. [CrossRef]

75. Fox, G. Influence of Diluent and of Copolymer Composition on the Glass Temperature of a Polymer System. Bull. Am. Phys. Soc. 1956, 1, 123.

76. Gigli, M.; Lotti, N.; Gazzano, M.; Finelli, L.; Munari, A. Novel eco-friendly random copolyesters of poly(butylene succinate) containing ether-linkages. React. Funct. Polym. 2012, 72, 303-310. [CrossRef]

77. Gigli, M.; Lotti, N.; Gazzano, M.; Finelli, L.; Munari, A. Macromolecular design of novel sulfur-containing copolyesters with promising mechanical properties. J. Appl. Polym. Sci. 2012, 126, 686-696. [CrossRef]

78. Genovese, L.; Gigli, M.; Lotti, N.; Gazzano, M.; Siracusa, V.; Munari, A.; Dalla Rosa, M. Biodegradable Long Chain Aliphatic Polyesters Containing Ether-Linkages: Synthesis, Solid-State, and Barrier Properties. Ind. Eng. Chem. Res. 2014, 53, 10965-10973. [CrossRef]

79. Norazlina, H.; Kamal, Y. Graphene modifications in polylactic acid nanocomposites: A review. Polym. Bull. 2015, 72, 931-961. [CrossRef]

80. Gonçalves, C.; Gonçalves, I.C.; Magalhães, F.D.; Pinto, A.M. Poly(lactic acid) Composites Containing Carbon-Based Nanomaterials: A Review. Polymers 2017, 9, 269. [CrossRef]

81. Bari, S.S.; Chatterjee, A.; Mishra, S. Biodegradable polymer nanocomposites: An overview. Polym. Rev. 2015, 56, 287-328. [CrossRef]

82. Zou, J.; Chen, X.; Jiang, X.B.; Zhang, J.; Guo, Y.B.; Huang, F.R. Poly(L-lactide) nanocomposites containing octaglycidylether polyhedral oligomeric silsesquioxane: Preparation, structure and properties. Express Polym. Lett. 2011, 5, 662-673. [CrossRef]

83. Bayer, S.I. Thermomechanical Properties of Polylactic Acid-Graphene Composites: A State-of-the-Art Review for Biomedical Applications. Materials 2017, 10, 748. [CrossRef] [PubMed]

84. Choi, W.M.; Kim, T.W.; Park, O.O.; Chang, Y.K.; Lee, J.W. Preparation and characterization of poly(hydroxybutyrate-co-hydroxyvalerate)-organoclay nanocomposites. J. Appl. Polym. Sci. 2003, 90, 525-529. [CrossRef]

85. Pal, N.; Dubey, P.; Gopinath, P.; Pal, K. Combined effect of cellulose nanocrystal and reduced graphene oxide into poly-lactic acid matrix nanocomposite as a scaffold and its anti-bacterial activity. Int. J. Biol. Macromol. 2017, 95, 94-105. [CrossRef] [PubMed]

86. Vert, M.; Doi, Y.; Hellwich, K.-H.; Hess, M.; Hodge, P.; Kubisa, P.; Rinaudo, M.; Schué, F. Terminology for biorelated polymers and applications (IUPAC Recommendations 2012). Pure Appl. Chem. 2012, 84, 377-410. [CrossRef]

87. Lucas, N.; Bienaime, C.; Belloy, C.; Queneude, M.; Silvestre, F.; Nava-Saucedo, J.E. Polymer biodegradation: Mechanisms and estimation techniques-A review. Chemosphere 2008, 73, 429-442. [CrossRef] [PubMed]

88. Gopferich, A. Mechanisms of polymer degradation and erosion. Biomaterials 1996, 17, 103-114. [CrossRef]

89. Li, S. Scaffolding in Tissue Engineering; Taylor \& Francis Group: Boca Raton, FL, USA, 2006; Chapter 23.

90. Mochizuki, M.; Hirami, M. Structural Effects on the Biodegradation of Aliphatic Polyesters. Polym. Adv. Technol. 1997, 8, 203-209. [CrossRef]

91. Grima, S.; Bellon-Maurel, V.; Feuilloley, P.; Silvestre, F. Aerobic Biodegradation of Polymers in Solid-State Conditions: A Review of Environmental and Physicochemical Parameter Settings in Laboratory Simulations. J. Polym. Environ. 2002, 8, 183-195. [CrossRef]

92. Kumar, S.; Maiti, P. Controlled biodegradation of polymers using nanoparticles and its application. RSC Adv. 2016, 6, 67449-67480. [CrossRef]

93. Gigli, M.; Negroni, A.; Soccio, M.; Zanaroli, G.; Lotti, N.; Fava, F.; Munari, A. Influence of chemical and architectural modifications on the enzymatic hydrolysis of poly(butylene succinate). Green Chem. 2012, 14, 2885-2893. [CrossRef] 
94. Pellis, A.; Acero, E.H.; Weber, H.; Obersriebnig, M.; Breinbauer, R.; Srebotnik, E.; Guebitz, G.M. Biocatalyzed approach for the surface functionalization of poly(L-lactic acid) films using hydrolytic enzymes. Biotechnol. J. 2015, 10, 1739-1749. [CrossRef] [PubMed]

95. Ortner, A.; Pellis, A.; Gamerith, C.; Orcal Yebra, A.; Scaini, D.; Kaluzna, I.; Mink, D.; De Wildeman, S.; Herrero Acero, E.; Guebitz, G.M. Superhydrophobic functionalization of cutinase activated poly(lactic acid) surfaces. Green Chem. 2017, 19, 816-822. [CrossRef]

96. Pellis, A.; Silvestrini, L.; Scaini, D.; Coburn, J.M.; Gardossi, L.; Kaplan, D.L.; Herrero Acero, E.; Guebitz, G.M. Enzyme-catalyzed functionalization of poly(L-lactic acid) for drug delivery applications. Process Biochem. 2017, 59, 77-83. [CrossRef]

97. Gigli, M.; Negroni, A.; Zanaroli, G.; Lotti, N.; Fava, F.; Munari, A. Environmentally friendly PBS-based copolyesters containing PEG-like subunit: Effect of block length on solid-state properties and enzymatic degradation. React. Funct. Polym. 2013, 73, 764-771. [CrossRef]

98. Gigli, M.; Negroni, A.; Soccio, M.; Zanaroli, G.; Lotti, N.; Fava, F.; Munari, A. Enzymatic hydrolysis studies on novel eco-friendly aliphatic thiocopolyesters. Polym. Degrad. Stab. 2013, 98, 934-942. [CrossRef]

99. Chen, H.; Gigli, M.; Gualandi, C.; Truckenmuller, R.; Van Bitterswijk, C.; Lotti, N.; Munari, A.; Focarete, M.L.; Moroni, L. Tailoring chemical and physical properties of fibrous scaffolds from block copolyesters containing ether and thio-ether linkages for skeletal differentiation of human mesenchymal stromal cells. Biomaterials 2016, 76, 261-272. [CrossRef] [PubMed]

100. Browning, A.; Chu, C.C. The effect of annealing treatments on the tensile properties and hydrolytic degradative properties of polyglycolic acid sutures. J. Biomed. Mater. Res. 1986, 20, 613-632. [CrossRef] [PubMed]

101. Gualandi, C.; Soccio, M.; Govoni, M.; Valente, S.; Lotti, N.; Munari, A.; Giordano, E.; Pasquinelli, G.; Focarete, M.L. Poly(butylene/diethylene glycol succinate) multiblock copolyester as a candidate biomaterial for soft tissue engineering: Solid-state properties, degradability, and biocompatibility. J. Bioact. Compat. Polym. 2012, 27, 244-264. [CrossRef]

102. Von Burkersroda, F.; Schedl, L.; Gopferich, A. Why degradable polymers undergo surface erosion or bulk erosion. Biomaterials 2002, 23, 4221-4231. [CrossRef]

103. Singh, N.K.; Purkayastha, B.D.; Roy, J.K.; Banik, R.M.; Yashpal, M.; Singh, G.; Malik, S.; Maiti, P. Nanoparticle-Induced Controlled Biodegradation and Its Mechanism in Poly(E-caprolactone). ACS Appl. Mater. Interfaces 2009, 2, 69-81. [CrossRef] [PubMed]

104. Gualandi, C.; Soccio, M.; Saino, E.; Focarete, M.L.; Lotti, N.; Munari, A.; Moroni, L.; Visai, L. Easily synthesized novel biodegradable copolyesters with adjustable properties for biomedical applications. Soft Matter 2012, 8, 5466-5476. [CrossRef]

105. Bikiaris, D.N. Nanocomposites of aliphatic polyesters: An overview of the effect of different nanofillers on enzymatic hydrolysis and biodegradation of polyesters. Polym. Degrad. Stab. 2013, 98, 1908-1928. [CrossRef]

106. Singh, N.K.; Purkayastha, B.P.D.; Panigrahi, M.; Gautam, R.K.; Banik, R.M.; Maiti, P. Enzymatic degradation of polylactide/layered silicate nanocomposites: Effect of organic modifiers. J. Appl. Polym. Sci. 2013, 127, 2465-2474. [CrossRef]

107. Armentano, I.; Dottori, M.; Puglia, D.; Kenny, J.M. Effects of carbon nanotubes (CNTs) on the processing and in-vitro degradation of poly(dl-lactide-co-glycolide)/CNT films. J. Mater. Sci. Mater. Med. 2008, 19, 2377-2387. [CrossRef] [PubMed]

108. Eker, B.; Asuri, P.; Murugesan, S.; Linhardt, R.J.; Dordick, J.S. Enzyme-Carbon Nanotube Conjugates in Room-temperature Ionic Liquids. Appl. Biochem. Biotechnol. 2007, 143, 153-163. [CrossRef] [PubMed]

109. Martino, S.; Tiribuzi, R.; Ciraci, E.; Makrypidi, G.; D’Angelo, F.; di Girolamo, I.; Gritti, A.; de Angelis, G.M.C.; Papaccio, G.; Sampaolesi, M.; et al. Coordinated involvement of cathepsins S, D and cystatin C in the commitment of hematopoietic stem cells to dendritic cells. Int. J. Biochem. Cell Biol. 2011, 43, 775-783. [CrossRef] [PubMed]

110. Martino, S.; di Girolamo, I.; Cavazzin, C.; Tiribuzi, R.; Galli, R.; Rivaroli, A.; Valsecchi, M.; Sandhoff, K.; Sonnino, S.; Vescovi, A.; et al. Neural precursor cell cultures from GM2 gangliosidosis animal models recapitulate the biochemical and molecular hallmarks of the brain pathology. J. Neurochem. 2009, 109, 135-147. [CrossRef] [PubMed] 
111. Calbi, V.; Fumagalli, F.; Consiglieri, G.; Penati, R.; Acquati, S.; Redaelli, D.; Attanasio, V.; Marcella, F.; Cicalese, M.P.; Migliavacca, M.; et al. Use of Defibrotide to help prevent post-transplant endothelial injury in a genetically predisposed infant with metachromatic leukodystrophy undergoing hematopoietic stem cell gene therapy. Bone Marrow Transplant. 2018, 53, 913-917. [CrossRef] [PubMed]

112. Frati, G.; Luciani, M.; Meneghini, V.; De Cicco, S.; Ståhlman, M.; Blomqvist, M.; Grossi, S.; Filocamo, M.; Morena, F.; Menegon, A.; et al. Human iPSC-based models highlight defective glial and neuronal differentiation from neural progenitor cells in metachromatic leukodystrophy. Cell Death Dis. 2018, 9, 698. [CrossRef] [PubMed]

113. Meneghini, V.; Frati, G.; Sala, D.; De Cicco, S.; Luciani, M.; Cavazzin, C.; Paulis, M.; Mentzen, W.; Morena, F.; Giannelli, S.; et al. Generation of Human Induced Pluripotent Stem Cell-Derived Bona Fide Neural Stem Cells for Ex Vivo Gene Therapy of Metachromatic Leukodystrophy. Stem Cells Transl. Med. 2017, 6, 352-368. [CrossRef] [PubMed]

114. Meneghini, V.; Lattanzi, A.; Tiradani, L.; Bravo, G.; Morena, F.; Sanvito, F.; Calabria, A.; Bringas, J.; Fisher-Perkins, J.M.; Dufour, J.P.; et al. Pervasive supply of therapeutic lysosomal enzymes in the CNS of normal and Krabbe-affected non-human primates by intracerebral lentiviral gene therapy. EMBO Mol. Med. 2016, 8, 489-510. [CrossRef] [PubMed]

115. Ungari, S.; Montepeloso, A.; Morena, F.; Cocchiarella, F.; Recchia, A.; Martino, S.; Gentner, B.; Naldini, L.; Biffi, A. Design of a regulated lentiviral vector for hematopoietic stem cell gene therapy of globoid cell leukodystrophy. Mol. Ther. Methods Clin. Dev. 2015, 2, 15038. [CrossRef] [PubMed]

116. Ricca, A.; Rufo, N.; Ungari, S.; Morena, F.; Martino, S.; Kulik, W.; Alberizzi, V.; Bolino, A.; Bianchi, F.; Del Carro, U.; et al. Combined gene/cell therapies provide long-term and pervasive rescue of multiple pathological symptoms in a murine model of globoid cell leukodystrophy. Hum. Mol. Genet. 2015, 24, 3372-3389. [CrossRef] [PubMed]

117. Lorioli, L.; Cesani, M.; Regis, S.; Morena, F.; Grossi, S.; Fumagalli, F.; Acquati, S.; Redaelli, D.; Pini, A.; Sessa, M.; et al. Critical issues for the proper diagnosis of Metachromatic Leukodystrophy. Gene 2014, 537, 348-351. [CrossRef] [PubMed]

118. Morena, F.; di Girolamo, I.; Emiliani, C.; Gritti, A.; Biffi, A.; Martino, S. A new analytical bench assay for the determination of Arylsulfatase A activity toward galactosyl-3-sulfate ceramide: Implication for metachromatic leukodystrophy diagnosis. Anal. Chem. 2014, 86, 473-481. [CrossRef] [PubMed]

119. Martino, S.; Montesano, S.; di Girolamo, I.; Tiribuzi, R.; Di Gregorio, M.; Orlacchio, A.; Datti, A.; Calabresi, P.; Sarchielli, P.; Orlacchio, A. Expression of cathepsins S and D signals a distinctive biochemical trait in CD34+ hematopoietic stem cells of relapsing-remitting multiple sclerosis patients. Mult. Scler. 2013, 19, 1443-1453. [CrossRef] [PubMed]

120. Martino, S.; Emiliani, C.; Tancini, B.; Severini, G.M.; Chigorno, V.; Bordignon, C.; Sonnino, S.; Orlacchio, A. Absence of metabolic cross-correction in Tay-Sachs cells: Implications for gene therapy. J. Biol. Chem. 2002, 277, 20177-20184. [CrossRef] [PubMed]

121. Martino, S.; Cavalieri, C.; Emiliani, C.; Dolcetta, D.; Cusella De Angelis, M.G.; Chigorno, V.; Severini, G.M.; Sandhoff, K.; Bordignon, C.; Sonnino, S.; et al. Restoration of the GM2 ganglioside metabolism in bone marrow-derived stromal cells from Tay-Sachs disease animal model. Neurochem. Res. 2002, 27, 793-8000. [CrossRef] [PubMed]

122. O'Brien, F.J. Biomaterials \& scaffolds for tissue engineering. Mater. Today 2011, 14, 88-95. [CrossRef]

123. D'Angelo, F.; Tiribuzi, R.; Armentano, I.; Kenny, J.M.; Martino, S.; Orlacchio, A. Mechanotransduction: Tuning stem cells fate. J. Funct. Biomater. 2011, 2, 67-87. [CrossRef] [PubMed]

124. Armentano, I.; Puglia, D.; Luzi, F.; Arciola, C.R.; Morena, F.; Martino, S.; Torre, L. Nanocomposites Based on Biodegradable Polymers. Materials 2018, 11, 795. [CrossRef] [PubMed]

125. Fortunati, E.; Aluigi, A.; Armentano, I.; Morena, F.; Emiliani, C.; Martino, S.; Santulli, C.; Torre, L.; Kenny, J.M.; Puglia, D. Keratins extracted from Merino wool and Brown Alpaca fibres: Thermal, mechanical and biological properties of PLLA based biocomposites. Mater. Sci. Eng. C Mater. Biol. Appl. 2015, 47, 394-406. [CrossRef] [PubMed] 
126. Martino, S.; D'Angelo, F.; Armentano, I.; Kenny, J.M.; Orlacchio, A. Stem cell-biomaterial interactions for regenerative medicine. Biotechnol. Adv. 2012, 30, 338-351. [CrossRef] [PubMed]

127. Howard, D.; Buttery, L.D.; Shakesheff, K.M.; Roberts, S.J. Tissue engineering: Strategies, stem cells and scaffolds. J. Anat. 2008, 213, 66-72. [CrossRef] [PubMed]

128. Fang, D.; Roskies, M.; Abdallah, M.-N.; Bakkar, M.; Jordan, J.; Lin, L.-C.; Tamimi, F.; Tran, S.D. Three-Dimensional Printed Scaffolds with Multipotent Mesenchymal Stromal Cells for Rabbit Mandibular Reconstruction and Engineering. Methods Mol. Biol. 2017, 1553, 273-291. [CrossRef] [PubMed]

129. Morena, F.; Argentati, C.; Calzoni, E.; Cordellini, M.; Emiliani, C.; D'Angelo, F.; Martino, S. Ex-Vivo Tissues Engineering Modeling for Reconstructive Surgery Using Human Adult Adipose Stem Cells and Polymeric Nanostructured Matrix. Nanomaterials 2016, 6, 57. [CrossRef] [PubMed]

130. Tarpani, L.; Morena, F.; Gambucci, M.; Zampini, G.; Massaro, G.; Argentati, C.; Emiliani, C.; Martino, S.; Latterini, L. The Influence of Modified Silica Nanomaterials on Adult Stem Cell Culture. Nanomaterials 2016, 6,104 . [CrossRef] [PubMed]

131. Pegg, D.E. Viability assays for preserved cells, tissues, and organs. Cryobiology 1989, 26, 212-231. [CrossRef]

132. Kuznetsova, D.S.; Timashev, P.S.; Dudenkova, V.V.; Meleshina, A.V.; Antonov, E.A.; Krotova, L.I.; Popov, V.K.; Bagratashvili, V.N.; Zagaynova, E.V. Comparative Analysis of Proliferation and Viability of Multipotent Mesenchymal Stromal Cells in 3D Scaffolds with Different Architectonics. Bull. Exp. Biol. Med. 2016, 160, 535-541. [CrossRef] [PubMed]

133. Carmichael, J.; DeGraff, W.G.; Gazdar, A.F.; Minna, J.D.; Mitchell, J.B. Evaluation of a tetrazolium-based semiautomated colorimetric assay: Assessment of chemosensitivity testing. Cancer Res. 1987, 47, $936-942$. [PubMed]

134. Denizot, F.; Lang, R. Rapid colorimetric assay for cell growth and survival. Modifications to the tetrazolium dye procedure giving improved sensitivity and reliability. J. Immunol. Methods 1986, 89, 271-277. [CrossRef]

135. Rescignano, N.; Tarpani, L.; Romani, A.; Bicchi, I.; Mattioli, S.; Emiliani, C.; Torre, L.; Kenny, J.M.; Martino, S.; Latterini, L.; et al. In-vitro degradation of PLGA nanoparticles in aqueous medium and in stem cell cultures by monitoring the cargo fluorescence spectrum. Polym. Degrad. Stab. 2016, 134, 296-304. [CrossRef]

136. Wehrle-Haller, B. Structure and function of focal adhesions. Curr. Opin. Cell Biol. 2012, 24, 116-124. [CrossRef] [PubMed]

137. Vercellino, M.; Ceccarelli, G.; Cristofaro, F.; Balli, M.; Bertoglio, F.; Bruni, G.; Benedetti, L.; Avanzini, M.A.; Imbriani, M.; Visai, L. Nanostructured $\mathrm{TiO}_{2}$ Surfaces Promote Human Bone Marrow Mesenchymal Stem Cells Differentiation to Osteoblasts. Nanomaterials 2016, 24, 124. [CrossRef] [PubMed]

138. Gauthier, N.C.; Roca-Cusachs, P. Mechanosensing at integrin-mediated cell-matrix adhesions: From molecular to integrated mechanisms. Curr. Opin. Cell Biol. 2018, 50, 20-26. [CrossRef] [PubMed]

139. Seetharaman, S.; Etienne-Manneville, S. Integrin diversity brings specificity in Mechanotransduction. Biol. Cell 2018, 110, 49-64. [CrossRef] [PubMed]

140. Chen, Y.; Ju, L.; Rushdi, M.; Ge, C.; Zhu, C. Receptor-mediated cell mechanosensing. Mol. Biol. Cell 2017, 28, 3134-3155. [CrossRef] [PubMed]

141. Alcaraz, J.; Otero, J.; Jorba, I.; Navajas, D. Bidirectional mechanobiology between cells and their local extracellular matrix probed by atomic force microscopy. Semin. Cell Dev. Biol. 2018, 73, 71-81. [CrossRef] [PubMed]

142. Priest, A.V.; Shafraz, O.; Sivasankar, S. Biophysical basis of cadherin mediated cell-cell adhesion. Exp. Cell Res. 2017, 358, 10-13. [CrossRef] [PubMed]

143. Hoffman, B.D.; Yap, A.S. Towards a Dynamic Understanding of Cadherin-BasedMechanobiology. Trends Cell Biol. 2015, 25, 803-814. [CrossRef] [PubMed]

144. Ziegler, W.H.; Liddington, R.C.; Critchley, D.R. The structure and regulation of vinculin. Trends Cell Biol. 2006, 16, 453-460. [CrossRef] [PubMed]

145. Carisey, A.; Ballestrem, C. Vinculin, an adapter protein in control of cell adhesion signalling. Eur. J. Cell Biol. 2011, 90, 157-163. [CrossRef] [PubMed]

146. Martino, S.; D'Angelo, F.; Armentano, I.; Tiribuzi, R.; Pennacchi, M.; Dottori, M.; Mattioli, S.; Caraffa, A.; Cerulli, G.G.; Kenny, J.M.; et al. Hydrogenated amorphous carbon nanopatterned film designs drive human bone marrow mesenchymal stem cell cytoskeleton architecture. Tissue Eng. Part A 2009, 15, 3139-3149. [CrossRef] [PubMed] 
147. Cheng, C.; Trzcinski, O.; Doering, L.C. Fluorescent labeling of dendritic spines in cell cultures with the carbocyanine dye "DiI". Front. Neuroanat. 2014, 8, 1-8. [CrossRef] [PubMed]

148. Available online: https://www.thermofisher.com/it/en/home/life-science/cell-analysis/cell-structure/ cytoskeleton/phalloidin-and-phalloidin-conjugates-for-staining-actin.html (accessed on 22 August 2018).

149. Semenova, I.; Rodionov, V. Fluorescence microscopy of microtubules in cultured cells. Methods Mol. Med. 2007, 137, 93-102. [PubMed]

150. Argentati, C.; Morena, F.; Montanucci, P.; Rallini, M.; Basta, G.; Calabrese, N.; Calafiore, R.; Cordellini, M.; Emiliani, C.; Armentano, I. Surface Hydrophilicity of Poly (L-Lactide) Acid Polymer Film Changes the Human Adult Adipose Stem Cell Architecture. Polymers 2018, 10, 140. [CrossRef]

151. Csaki, C.; Schneider, P.R.A.; Shakibaei, M. Mesenchymal stem cells as a potential pool for cartilage tissue engineering. Ann. Anat. Anat. Anz. 2008, 190, 395-412. [CrossRef] [PubMed]

152. Chang, H.H.; Hemberg, M.; Barahona, M.; Ingber, D.E.; Huang, S. Transcriptome-wide noise controls lineage choice in mammalian progenitor cells. Nature 2008, 453, 544-547. [CrossRef] [PubMed]

153. Fagerberg, L.; Hallström, B.M.; Oksvold, P.; Kampf, C.; Djureinovic, D.; Odeberg, J.; Habuka, M.; Tahmasebpoor, S.; Danielsson, A.; Edlund, K.; et al. Analysis of the human tissue-specific expression by genome-wide integration of transcriptomics and antibody-based proteomics. Mol. Cell. Proteom. 2014, 13, 397-406. [CrossRef] [PubMed]

154. Reik, W. Stability and flexibility of epigenetic gene regulation in mammalian development. Nature 2007, 447, 425-432. [CrossRef] [PubMed]

155. D’Angelo, F.; Armentano, I.; Mattioli, S.; Crispoltoni, L.; Tiribuzi, R.; Cerulli, G.G.; Palmerini, C.A.; Kenny, J.M.; Martino, S.; Orlacchio, A. Micropatterned hydrogenated amorphous carbon guides mesenchymal stem cells towards neuronal differentiation. Eur. Cells Mater. 2010, 5, 231-244. [CrossRef]

156. Cristofaro, F.; Gigli, M.; Bloise, N.; Chen, H.; Bruni, G.; Munari, A.; Moroni, L.; Lotti, N.; Visai, L. Influence of the nanofiber chemistry and orientation of biodegradable poly(butylene succinate)-based scaffolds on osteoblast differentiation for bone tissue regeneration. Nanoscale 2018, 10, 8689-8703. [CrossRef] [PubMed]

157. Salvi, A.M.; DeMali, K.A. Mechanisms linking mechanotransduction and cell metabolism. Curr. Opin. Cell Biol. 2018, 54, 114-120. [CrossRef] [PubMed]

158. Smith, L.R.; Cho, S.; Discher, D.E. Stem Cell Differentiation is Regulated by Extracellular Matrix Mechanics. Physiology 2018, 33, 16-25. [CrossRef] [PubMed]

159. Malinova, T.S.; Huveneers, S. Sensing of Cytoskeletal Forces by Asymmetric Adherens Junctions. Trends Cell Biol. 2018, 28, 328-341. [CrossRef] [PubMed]

160. Uhler, C.; Shivashankar, G.V. Regulation of genome organization and gene expression by nuclear mechanotransduction. Nat. Rev. Mol. Cell Biol. 2017, 18, 717-727. [CrossRef] [PubMed]

161. Engler, J.; Sen, S.; Sweeney, H.L.; Discher, D.E. Matrix Elasticity Directs Stem Cell Lineage Specification. Cell 2006, 126, 677-689. [CrossRef] [PubMed]

162. Martino, F.; Perestrelo, A.R.; Vinarský, V.; Pagliari, S.; Forte, G. Cellular Mechanotransduction: From Tension to Function. Front. Physiol. 2018, 9, 824. [CrossRef] [PubMed]

163. Charras, G.; Yap, A.S. Tensile Forces and Mechanotransduction at Cell-Cell Junctions. Curr. Biol. 2018, 28, R445-R457. [CrossRef] [PubMed]

164. Kirby, T.J.; Lammerding, J. Emerging views of the nucleus as a cellular Mechanosensor. Nat. Cell Biol. 2018, 20, 373-381. [CrossRef] [PubMed]

165. Bosch-Fortea, M.; Martín-Belmonte, F. Mechanosensitive adhesion complexes in epithelial architecture and cancer onset. Curr. Opin. Cell Biol. 2018, 50, 42-49. [CrossRef] [PubMed]

166. Ladoux, B.; Mège, R.M. Mechanobiology of collective cell behaviours. Nat. Rev. Mol. Cell Biol. 2017, 18, 743-757. [CrossRef] [PubMed]

167. Heo, S.J.; Cosgrove, B.D.; Dai, E.N.; Mauck, R.L. Mechano-adaptation of the stem cell nucleus. Nucleus 2018, 9, 9-19. [CrossRef] [PubMed]

168. Athirasala, A.; Hirsch, N.; Buxboim, A. Nuclear mechanotransduction: Sensing the force from within. Curr. Opin. Cell Biol. 2017, 46, 119-127. [CrossRef] [PubMed] 
169. Friedrich, O.; Schneidereit, D.; Nikolaev, Y.A.; Nikolova-Krstevski, V.; Schürmann, S.; Wirth-Hücking, A.; Merten, A.L.; Fatkin, D.; Martinac, B. Adding dimension to cellular mechanotransduction: Advances in biomedical engineering of multiaxial cell-stretch systems and their application to cardiovascular biomechanics and mechano-signaling. Prog. Biophys. Mol. Biol. 2017, 130, 170-191. [CrossRef] [PubMed]

170. Miroshnikova, Y.A.; Nava, M.M.; Wickström, S.A. Emerging roles of mechanical forces in chromatin regulation. J. Cell Sci. 2017, 130, 2243-2250. [CrossRef] [PubMed] 